\title{
REGIONAL PRECIPITATION TRENDS SINCE 1500 CE, RECONSTRUCTED FROM \\ CALCITE SUBLAYERS OF A VARVED MEDITERRANEAN LAKE RECORD \\ (CENTRAL PYRENEES)
}

Teresa Vegas-Vilarrúbia ${ }^{1,}$, Juan Pablo Corella ${ }^{\mathrm{b}}$, Javier Sigróc $^{c}, V$ Valentí Rull $^{\mathrm{d}}$, Isabel DoradoLiñan $^{\mathrm{e}}$, Blas Valero-Garcés ${ }^{\mathrm{f}}$, Emilia Gutiérrez $^{\mathrm{a}}$

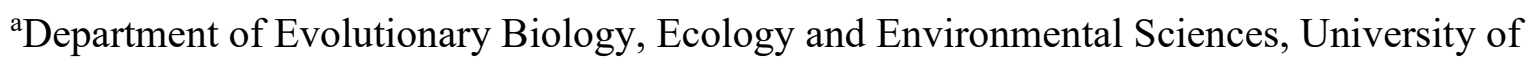
Barcelona, Av. Diagonal 643,08028 Barcelona, Spain.tvegas@ub.edu

${ }^{\text {b} C I E M A T, ~ E n v i r o n m e n t a l ~ D e p a r t m e n t, ~ A v . ~ C o m p l u t e n s e ~ 40, ~} 28040$ Madrid, Spain.

JuanPablo.Corella@ciemat.es

${ }^{\mathrm{c}} \mathrm{C} 3{ }^{-}$Centre for Climate Change, Dept. of Geography, University Rovira i Virgili, Spain. Javiersigro@urv.cat

${ }^{\mathrm{d}}$ Botanic Institute of Barcelona (CSIC), Passeig del Migdia s/n, 08038 Barcelona, Spain. vrull@ibb.csic.es

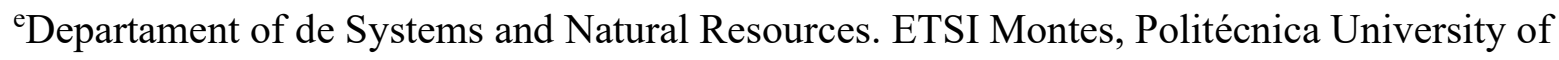
Madrid, Madrid, Spain. isabel.dorado@upm.es

f Instituto Pirenaico de Ecología, Consejo Superior de Investigaciones Científicas, Avda Montañana 1005, 50059 Zaragoza, Spain.blas@ipe.csic.es

\section{${ }^{1}$ CORRESPONDING AUTHOR}

Department of Evolutionary Biology, Ecology and Environmental Sciences, University of Barcelona, Av. Diagonal 643,08028 Barcelona, Spain.tvegas@ub.edu 


\begin{abstract}
The Mediterranean is one of the regions of the world where human-induced climate warming is expected to have large impacts on water and environmental resources. To predict shifts in the current climate system, more regional climate records, including seasonal-to-century scale variability spanning longer than the instrumental periods, are needed. To help fill this gap, we provide a reconstruction of autumn precipitation variations for the Central Pyrenees range since 1500 Common Era (CE) using the varved sediments of Lake Montcortès. To assess the suitability of the calcite sublayer width of the sediments of this lake as a proxy for precipitation anomalies, we performed an analysis and smoothing of the temporal structure of the width series, calibration of the new series with the available instrumental climate records, calculation of a transfer function and testing and comparison of the reconstructed series against available empirical data.
\end{abstract}

The prediction model was statistically robust and showed that the climatic signal was captured in the calcite sublayers. The reconstruction provides the first estimations of regional autumn precipitation shifts in the Central Pyrenees at annual resolution, since $1500 \mathrm{CE}$. Pronounced interdecadal shifts in precipitation were noticeable; no increasing nor decreasing linear trends or periods of extreme precipitation events were identified. The reconstructed precipitation anomalies suggest a decrease in rainfall during the coldest phase within the coldest period of the Little Ice Age and also during the $20^{\text {th }}$ century, probably associated to current Global Warming. Correlations between autumn precipitation and the North Atlantic Oscillation, Western Mediterranean Oscillation and Southern Oscillation indices were weak to moderate. A potential relationship with the Atlantic Multidecadal Oscillation pattern is suggested. The reconstructed 
autumn precipitation trends are coherent with other palaeohydrological reconstructions in similar Mediterranean settings, and consistent at a regional level.

KEYWORDS: Authigenic varves, Autumn precipitation, Climate warming, Little Ice Age, Transfer function model, Water resources 


\section{INTRODUCTION}

The Mediterranean is one of the regions where human-induced climate warming will have important consequences on the hydrological cycle. Climate models predict an increase in the annual average temperature between $2{ }^{\circ} \mathrm{C}$ in winter and between $3-6^{\circ} \mathrm{C}$ in summer until 2100 and forecast a $15 \%(25 \%)$ decrease in precipitation in October-March season (April-September season) (IPCC, 2021), which is likely larger than natural variations by the end of the 21 st century in some seasons (IPCC, 2021). If these predictions turn out to be true, living conditions would notably worsen, and secular problems related to the variability of the hydrological cycle would be aggravated, such as desertification and water resource availability and management.

In the Mediterranean region, the wet season falls between October and March, but seasonal patterns show large spatial variability. The complex topography of this region induces additional thermal and orographic forcing (Fernández et al., 2017; Xoplaki et al., 2004), and seasonal dependence from the contrast between land-ocean warming, thermodynamic circulation changes and atmospheric state (Brogli et al., 2019) enhances the natural variability of rainfall, thereby making estimations difficult. For example, on the Iberian Peninsula (IP), the climate is dominated by subtropical and mid-latitude air masses that move across it, and precipitation variability is controlled by low-pressure mid-latitude cyclonic circulation. This complex pattern is further complicated by the effect of mountain ranges with altitudes over $2000 \mathrm{~m}$ that extend east to west and split the territory into multiple subclimatic conditions (see review of Oliva et al., 2018; and literature therein Castro et al., 2020). Precipitation in the northern IP is mostly related to winter Atlantic fronts with a strong correlation with the NAO, SCAND and ENSO (Rodriguez-Puebla et al., 1998). In more Mediterranean regions, convective autumn and summer precipitation may also be a large contribution (Campins et al., 2000). On the Iberian Peninsula, 
cold season rainfall is strongly correlated with the North Atlantic Oscillation (NAO), the Mediterranean Oscillation (MO) and the Western Mediterranean Oscillation (WeMO) (MartinVide and Lopez-Bustins, 2006; Trigo et al., 2004).

Regional simulations show contrasting scenarios of temperature increases up to $5^{\circ} \mathrm{C}$ and precipitation decreases with strong spatial and temporal variability by the end of the $21^{\text {st }}$ century (Barrera-Escoda and Cunillera, 2011; Calbó et al., 2010; López-Moreno and Beniston, 2009). For the next few decades (2021-2050), average temperature increases of approximately $1.3{ }^{\circ} \mathrm{C}$ to $2.3{ }^{\circ} \mathrm{C}$ and precipitation decreases of between $-5 \%$ and $-20 \%$ (Fernández et al., 2017) are expected compared with the 1971-2020 period.

Several hydrological reconstructions spanning the last millennium for the Pyrenees and NE Iberian Peninsula are available based on tree ring (Génova, 2012), cave (Moreno et al., 2017; Stoll et al., 2013) and lake records (Corella et al., 2014, 2021; Morellón et al., 2011, 2012; Moreno et al., 2012; Pla and Catalan, 2005). These records show colder conditions and large hydrological variability during the Little Ice Age (LIA), a transition to the Industrial and Postindustrial Era and the recent global warming. These reconstructions of past precipitation are mostly qualitative. At a pan-Mediterranean scale, a see-saw pattern between the eastern and western Mediterranean has been suggested for precipitation variability during the last millennia (Roberts et al., 2012).

To better understand and predict shifts in the current climate system, we need more climate time series covering seasonal-to-century scale climate variability. The existing instrumental records rarely cover the natural long-term and spatial variability of precipitation; therefore, the development of highly reliable models to project precipitation scenarios over large areas and for decades and centuries to come is a complex task. In the Mediterranean region, 
some long instrumental climatic time series going back to the $17^{\text {th }}$ century and documentary records are available, as well as a rich body of indicators (proxies) that potentially allow for longer reconstructions. The available paleoclimatic reconstructions of precipitation for the last millennia show a heterogeneous picture owing to the intrinsic variability of the Mediterranean climate, and palaeohydrological changes are by far less documented than temperature changes (Luterbacher et al., 2012). The reasons for this situation are chiefly the low number of reconstructions based on well-dated and high-resolution proxies and the sparse spatial distribution.

However, the available evidence highlights that the Mediterranean region has gone through successive humid and dry periods that significantly affect the environment. Reconstruction-based estimations of precipitation variability have been made for the entire Mediterranean region, but these reconstructions may contain significant underestimations of the real values due to the abovementioned issues. In fact, what has been stated a decade ago holds true even still - a consistent reconstruction of precipitation over the Mediterranean region has yet to be completed (Lionello et al., 2012). In this context, the aim of the research presented in this paper is to help fill this gap.

In this paper, we assess the suitability of varve calcite sublayer widths of Lake Montcortès as a proxy for annual regional precipitation based on calibration with instrumental climate records and tested against available empirical data. The varves from this lake are of authigenic origin and are composed of a couplet of calcite and organic matter layers and occasional detrital layers (Corella et al., 2011, 2012). In other locations, the width of varve calcite sublayers has successfully been used as a proxy for temperature and precipitation (e.g., Amann et al., 2015, 2017; Besonen et al., 2008; Gajewski et al., 1997; Hardy et al., 1996; 
Hughen et al., 2000; Romero-Viana et al., 2008, 2011). We use the obtained temporal series to build a prediction model and provide the first reconstruction of regional precipitation in the Central Pyrenees since 1500 CE. Our research time window comprises the coldest conditions of the Little Ice Age (LIA), the transition between natural climate variability at the end of the LIA, and the Industrial and Post-industrial Era. The beginning of the latter marks the advent of a period where climatic variability also responds to increasing anthropogenic greenhouse gases. We discuss the strengths and limitations of the model and compare the results with other similar Mediterranean settings.

\section{REGIONAL SETTINGS}

Lake Montcortès is situated on the southern flank of the Central Pyrenees (Iberian Peninsula) at $42^{\circ} 19^{\prime} \mathrm{N}, 0^{\circ} 59^{\prime} \mathrm{E}$ and $1027 \mathrm{~m}$ altitude (Fig. 1). The lake lies on karst terrain composed of Triassic limestones, marls and evaporites, as well as Oligocene-carbonate conglomerates (Corella et al., 2011; Rosell, 1994). According to the near La Pobla de Segur meteorological station (554 m.a.s.1., $19 \mathrm{~km}$ from Montcortès), the total annual mean precipitation is $669 \mathrm{~mm}$. The annual mean temperature is $12.8^{\circ} \mathrm{C}$, and the maximum and minimum annual air temperatures are 41 and $-20^{\circ} \mathrm{C}$, respectively (Meteocat, 2015). The surrounding vegetation is evergreen with deciduous oak forests (Quercus rotundifolia and $Q$. pubescens), conifer forests (Pinus nigra), pastures and crops. The littoral belt vegetation is dominated by hygrophyte communities of Typha domingensis or Cladium mariscus, reed beds of Phragmites australis, communities of Carex riparia, and rush formations and grasslands on sporadically flooded soils (Mercadé et al., 2013). The lake surface is approximately $0.14 \mathrm{~km}^{2}$, with a maximum water depth of $32 \mathrm{~m}$ (Corella et al., 2019). There is no permanent inlet, and the maximum lake level is 
controlled by an ephemeral outlet brook located on the northern shore. The lake is mesooligotrophic, and the mixing regime is meromixic with occasional holomixis (Trapote et al., 2018a; Vegas-Vilarrúbia et al., 2018). Phytoplankton are dominated by Bacillarophytes and Chlorophytes, which flourish in early spring and summer, with the biomass being lowest in winter. The highest biovolume values reach $>6 \times 10^{6} \mu \mathrm{m}^{3} / \mathrm{mL}$ in summer. (Vegas-Vilarrúbia et al., 2020).
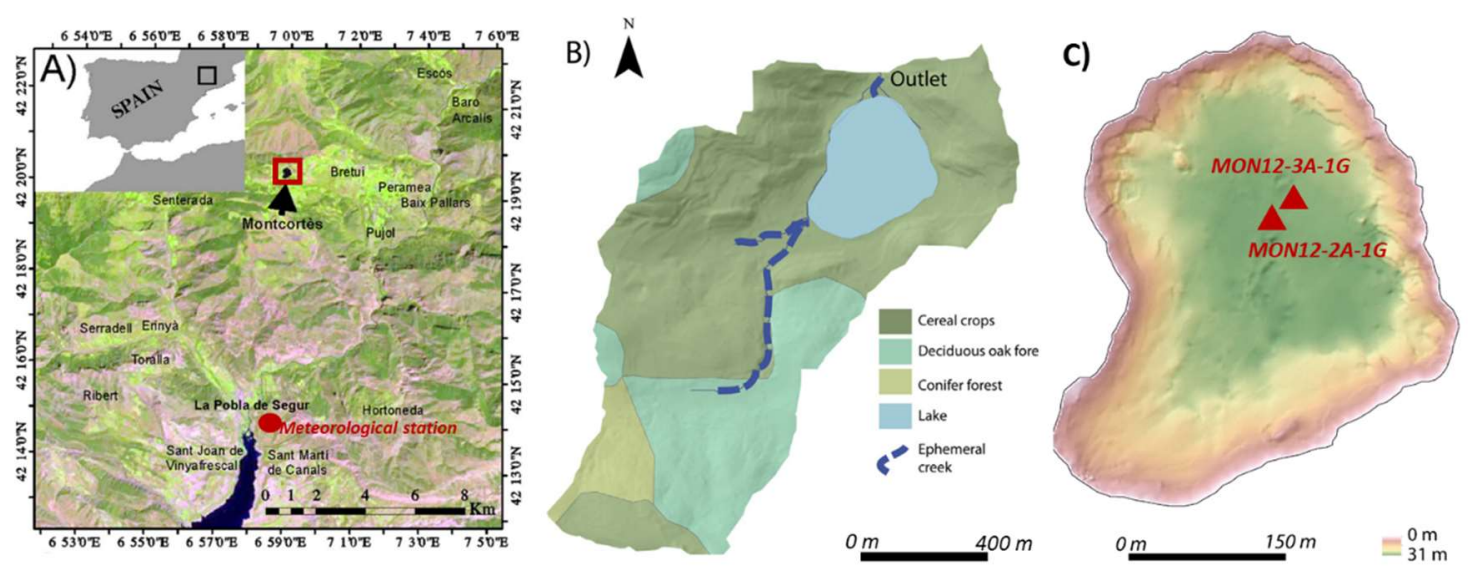

Figure 1: A) Geographical location within the Iberian Peninsula and regional map showing Lake Montcortès (red square) and the La Pobla de Segur meteorological station (red point) (modified from Trapote et al., 2018b); B) Vegetation map from lake Montcortès watershed (modified from Corella et al., 2014); C) Bathymetric map from the lake and location of the studied sediment cores (modified from Corella et al., 2019).

Meromixis creates suitable conditions for varve formation and preservation, and indeed, a continuous sequence of biogenic varves spans the last 3000 years. These varves are formed by couplets of light calcite and brownish organic layers (Corella et al., 2011, 2012, 2014) that were deposited in summer/fall and winter/spring, respectively (Trapote et al., 2018b)). At present, 
seasonal calcite sedimentation patterns are strongly linked with primary producers and are sensitive to temperature shifts (Trapote et al., 2018b; Vegas-Vilarrúbia et al., 2018, 2020). Occasionally, detrital layers related to intense run-off events punctuate the varve succession. A detailed description of the varved sediment of Lake Montcortès covering the last 500 years is available in Corella et al. (2012, 2014).

During the study period, human activities affected both the lake basin and the lake itself (Corella et al., 2019; Rull, 2015; Rull and Vegas-Vilarrúbia, 2014; Trapote et al., 2018a; VegasVilarrúbia et al., 2018). At the beginning of the period of our study (1500 CE), the town of Montcortès was home to 50-80 inhabitants. By $1500 \mathrm{CE}$, pastures and husbandry underwent significant diversification and expansion to the detriment of conifer forest, which was burned to manage the landscape. Forest clearing, burning, and hemp production became important human activities with eutrophication potential, especially during the eighteen and nineteen centuries. During the subsequent five decades, commercial activities and the subsistence economy went into crisis, forcing part of the population to emigrate. During the Industrial Revolution, a new dramatic crisis came about as a consequence of the mechanization of field labour and emigration to large industrialised areas. The number of inhabitants in Montcortès town decreased to 26 in $2015 \mathrm{CE}$, which was the lowest number of inhabitants recorded during the last 500 years.

\section{MATERIALS AND METHODS}

\subsection{Instrumental records of climatic variables}

We examined the concordance between climate variables of the central Pyrenees and the signals registered in the calcite varve sublayers $(\mathrm{CaL})$ to explore intercalibration possibilities and, if 
appropriate, to provide varved-based reconstructions of climate variables. To this end, we worked with the daily datasets of precipitation (PPT) and average, maximum, and minimum temperature values (Tmean, Tmax, Tmin) for the central Pyrenees covering the period 19102013 (Pérez-Zanón et al., 2016). This climate series represents the longest high-quality and homogenized climate dataset available for the central Pyrenees region, including the newly recovered period 1910-1949. We used the annual, seasonal, and monthly anomaly (1961-1990) regional series calculated from the daily data and available at http://www.c3.urv.cat/climadata.php. The regional series represents the signal from 150 individual series for precipitation and 126 individual series for Tmean, Tmax, and Tmin. This series is quality controlled with ExtraQC routines from RClimdex software, developed through the International Expert Team on Climate Change Detection and Indices (http://www.c3.urv.cat/data/soft/rclimdex_extraqc.zip), and its homogeneity has been tested and adjusted with a homogenization method developed during the HOME Cost Action (Venema et al., 2012), called HOMER (Mestre et al., 2013). The regional time series were constructed by averaging daily anomalies and then adding back the base-period mean according to the method of Jones and Hulme (1996) of separating temperature into its two components (the climatology and the anomaly). To adjust the variance bias present in regional mean time series associated over time with varying sample sizes, we applied the approach developed by Osborn et al. (1997).

\subsection{The varve record and reconstruction of the response variable}

Our study is based on sediment cores MON12-3A-1G and MON12-2A-1G retrieved from the deepest basin of Lake Montcortès (Fig. 1). Hammering was avoided during coring operations to minimize sediment disturbance. The sediment cores were stored for five days in the lake shore to 
favour sediment consolidation before transport to the laboratory. Once there, the sediment core was split and sampled for thin sections. Thus, large-scale thin sections (120 mm X $35 \mathrm{~mm})$ were prepared after sampling in aluminium trays, freeze-drying and impregnation in epoxy resin following the methodology described by Brauer and Casanova (2001). To carry out the palaeohydrological reconstruction for the last five centuries, a composite $88 \mathrm{~cm}-$ long sedimentary sequence using the two sediment cores was obtained that spanned from 1500 to 2012 CE. The age-depth model was based on two independent dating techniques: i) varve counting performed on $\mathrm{CaL}$ and ii) radiometric dating with ${ }^{210} \mathrm{~Pb},{ }^{137} \mathrm{Cs}$ and ${ }^{14} \mathrm{C}$ (see Corella et al. 2012, 2014). CaL width measurements were performed with an optical microscope on largescale thin sections. Calcite varve counting was performed by double counting in 11 overlapping thin sections ( $2 \mathrm{~cm}$ overlap). The upper $1 \mathrm{~cm}$ was disturbed, and thus, $\mathrm{CaL}$ thickness for the 2002-2012 period could not be achieved. The widths of CaL were measured at 50× magnification in each varve, except for the ones interpolated due to poor preservation $(<1 \%$ of total varve number); the mean width was $0,314 \mathrm{~mm} \pm 0.007 \mathrm{~mm}$ (see Corella et al. 2012, 2014 for methodological descriptions). Occasional micro-erosion or CaL below a turbidite deposit might bias sublayer thickness measurements, as underflow events may lead to microscopic scouring of the sediments underneath (Corella et al., 2014). Approximately $6 \%$ of the annual varves show a turbidite deposit, although clear erosional features are rare and mainly restricted to the period 1852-1902 CE, when abundant floods in the watershed took place (Corella et al., 2014).

To test whether the raw $\mathrm{CaL}$ series was unaffected by any significant age trend along the record (Maier et al., 2013), it was detrended by fitting a cubic smoothing spline of $67 \%$ of the series length with a $50 \%$ frequency response cut-off to the raw series. The detrended series, CaL67, is the series of residuals calculated by dividing the measured calcite width values by the 
estimated ones. This new series was used to determine the relationship with climate variables and to assess the periods of preferential oscillations superimposed on the general trend. We then investigated likely relationships between seasonal and annual variations in CaL67 and the meteorological records of PPT, Tmean, Tmax, and Tmin over the 20th century by computing Pearson correlation coefficients. We worked with conventional climatic seasons and with "nonconventional seasons". The latter were formed by different clusters of months that were related with periods of annual calcite sublayers forming biological activity (Trapote et al., 2018b). These seasonal series were calculated as averages of monthly values for temperatures and as accumulated values for precipitation. To estimate response variables (climatic) from predictor variables (CaL67), we applied ordinary least square (OLS) regression models and examined their statistical appropriateness. To this end, different sets of graphic regression diagnostic techniques were chosen (Kabacoff, 2011). The "car" statistical package was run to test the assumptions of the OLS regression, i.e., normality, independence, linearity, and homoscedasticity and to inform relevant individual observations (e.g., outliers, leverage, influence) based on Cook's D value. Residuals from the fitted models were semistudentized or studentized to keep variance constant for different xi and for the sake of comparability among residuals (Quinn and Keough, 2007). The Durbin-Watson statistic was used to detect the presence of autocorrelation in the residuals. Alternatively, assumptions of the linear models were validated by performing the "Global test for linear model assumptions" with the "gvlma" statistical package.

The reconstruction of the target climate variable from the detrended calcite series, CaL67, was based on the methodology and free software of Macias-Fauria et al. (2012), which includes two MATLAB-based programs, CorrelWindows and ReconstatsWindows. CorrelWindows computes correlations between time series by considering autocorrelation of the series. 
ReconstatsWindows allows reconstructing the climate variable, estimating the parameters needed for validation of the reconstructed climate variables and calculating the corresponding confidence intervals. The program is based on time series modelling and uses a high number of Monte Carlo iterations (10,000 in this research) to generate surrogate time series data, which are required to produce empirical density functions of probability. These functions were generated for all the statistical parameters involved in the validation-calibration tests of the reconstructed variable and permit us to estimate their value and significance. To create proper surrogate time series, we selected the frequency-domain procedure known as Ebisuzaki's approach, which generates random time series with the same power spectrum as the original series but with a random phase.

After examining the sensitivity of CaL67, we selected the climatic variable showing the highest relationship with CaL67. With ReconstatsWindows, we established the corresponding transfer function (linear regression) for the full calibration period to model the relationship CaL67 and the instrumental climatic data over the period 1910-2002. Then, the CaL67 data series and the climate record were split into two equally long subperiods for cross calibration and verification. For each subperiod, CaL67 series was regressed against the instrumental monthly temperature and precipitation records, and the model derived was used to predict the second half of the split instrumental record.

To assess the occurrence of low-frequency (LF) and high-frequency (HF) periodicity of the reconstructed climatic variable, we used Morlet's continuous wavelet transform (CWT) analysis (Zhang and Moore, 2011) using the PAST statistical package (Hammer et al., 2001) for computation. 


\section{RESULTS}

\subsection{Temporal structure of the series of calcite sublayer thicknesses}

The raw data series of calcite sublayer thickness (raw CaL) showed a significant trend likely due to compaction (Maier et al., 2013) and regular oscillations at various frequencies (Fig. 2A). The long-term trend (red noise) was removed in order: 1) to detect whether other significant frequencies of variability were present and, if affirmative, to determine the corresponding periods and 2) to search for significant relationships with climatic variables, i.e., PPT and temperature. The raw CaL series was detrended with a low pass filter by fitting a cubic smoothing spline of $67 \%$ of the series length and with a $50 \%$ frequency response cut-off to the raw series. The resulting time series, which is the residual CaL67 (Fig. 2B), is stationary in the mean $\left(\mathrm{CaL} 67_{\text {mean }}=1\right)$ but not in the variance. It is no longer affected by the long-term trend and maintains the oscillations at low a medium frequency. Indeed, the results of the spectral analysis reveal significant frequencies of variation that correspond to different periods of oscillation (Table S1). 
A)

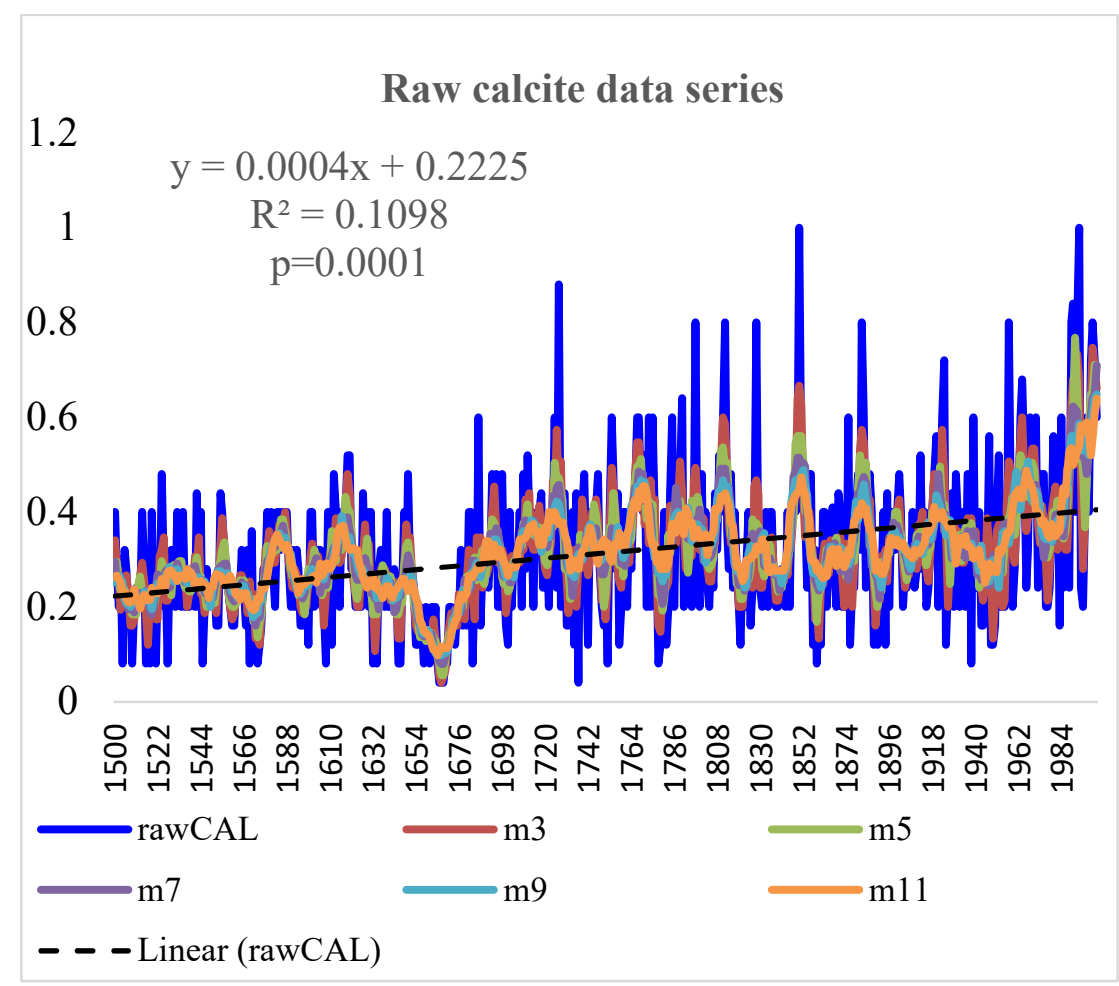

B)

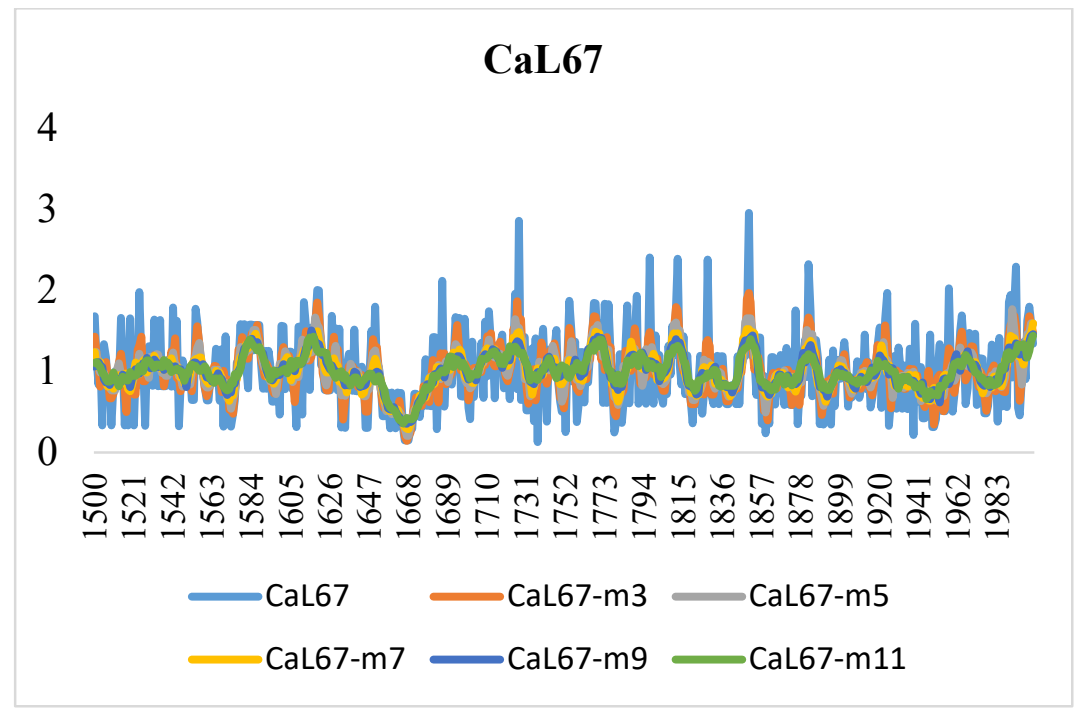

Figure 2: A) Raw and smoothed calcite data series using moving averages from 3 to 11 years.

B) Calcite series filtered with a cubic spline (CaL67) and smoothed using moving averages from 3 to 11 years. 


\subsection{Correlations between CaL67 and selected climate variables}

We evaluated the relationships between CaL67 and selected climatic variables by using bootstrap correlations, i.e., precipitation, and maximum and minimum temperatures (Fig. 3). The analysis was performed for the entire period covered with instrumental climatic data (1910-2002) and for two subperiods (1910-1956 and 1957-2002). The results yielded rather low and few significant correlation values. The influence of precipitation on varve thickness proved to be positive and that of temperature was negative in many months, especially in autumn and in summer along the intervals 1910-56 and 1957-2002, respectively.

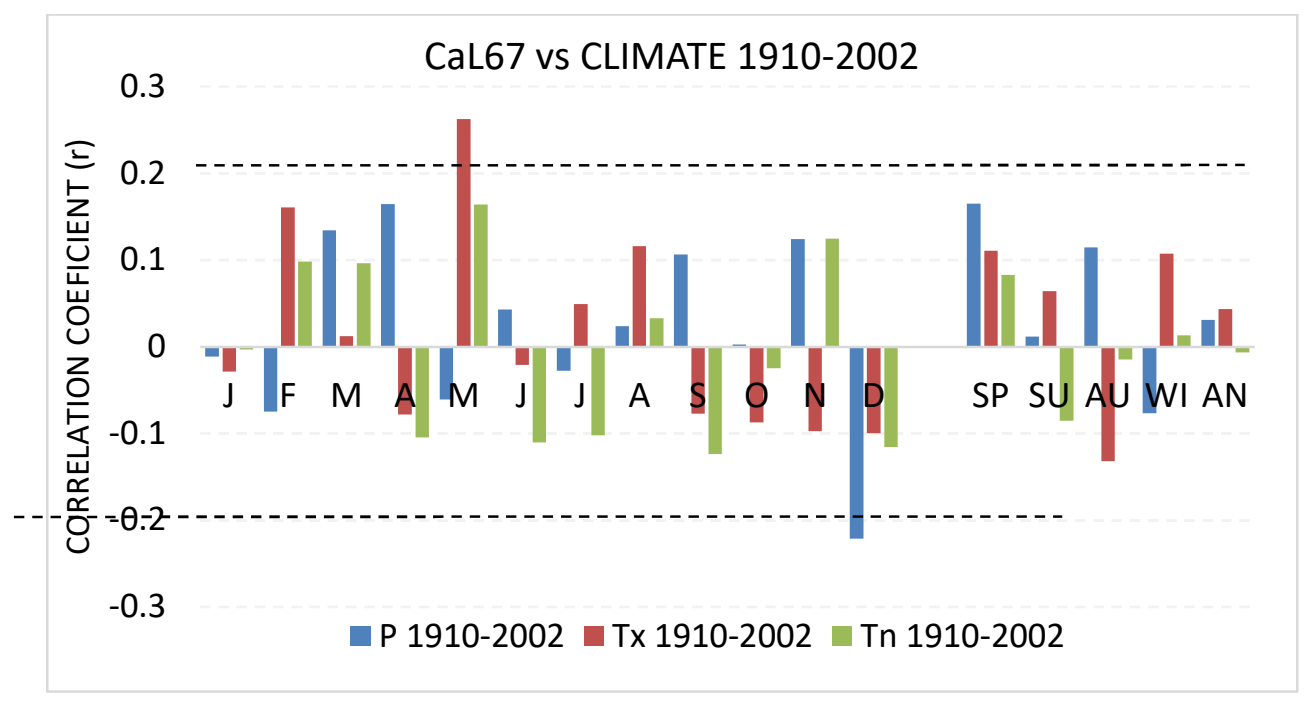



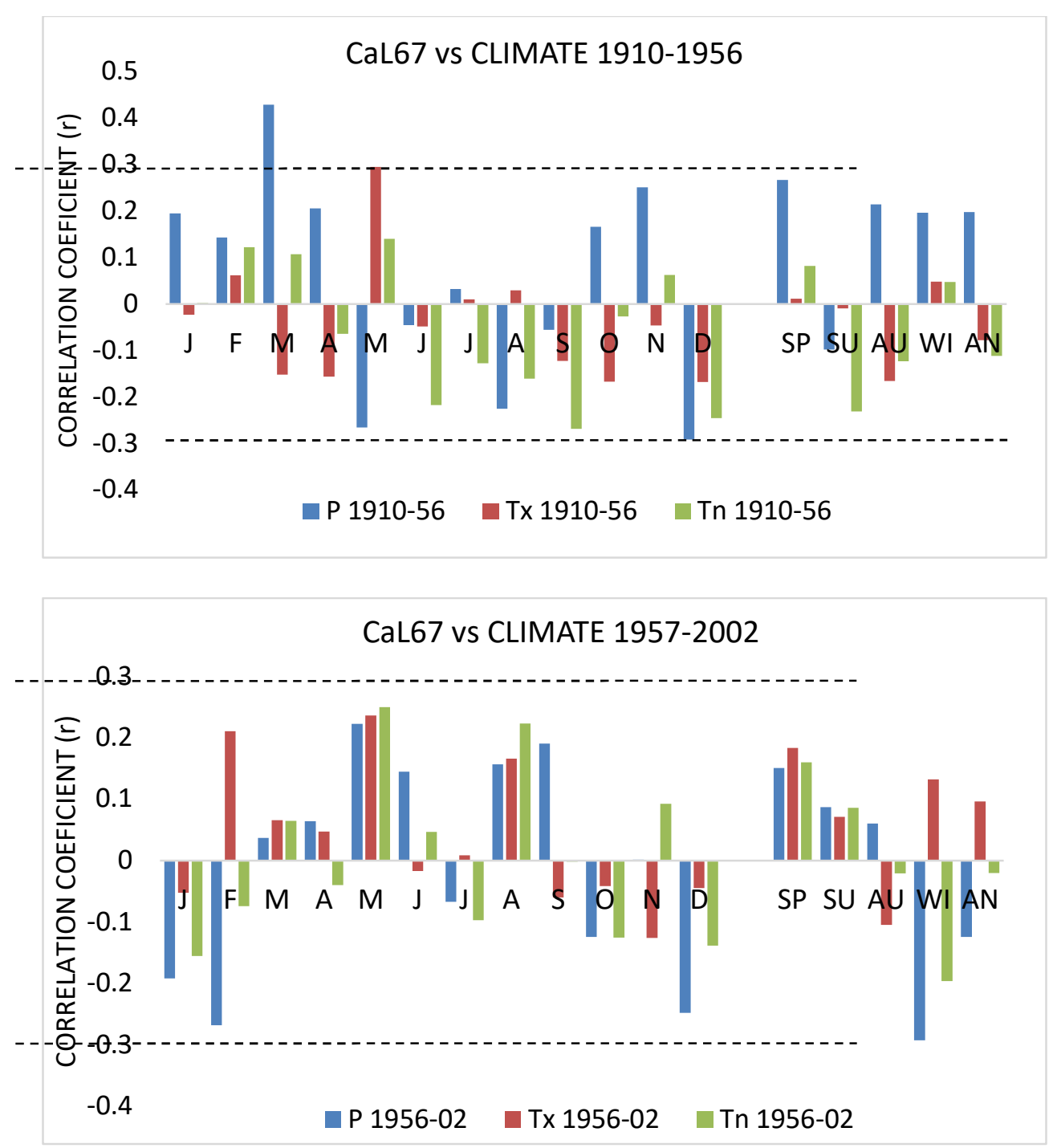

Figure 3. - Bootstrap correlation coefficients between CaL67 and monthly, seasonal and annual climatic variables. The level of significance, $\mathrm{p}$-values $<0.05$, is represented by the horizontal lines. $\mathrm{P}$, precipitation. $\mathrm{Tx}$, average maximum temperature. $\mathrm{Tn}$, average minimum temperature. SP, spring. SU, summer. AU, autumn. WI, winter. AN, annual.

For the interval 1910-2002, only precipitation in December $(r=-0.221, p=0.033)$ and May mean maximum temperatures $(\mathrm{r}=0.263, \mathrm{p}=0.011)$ were significantly related to CaL67. Interestingly, the two subintervals revealed clear differences among them. Between 1910 and 
1956, precipitation in March showed the most significant and positive correlations with calcite sublayer thickness $(\mathrm{r}=0.428, \mathrm{p}=0.003)$. The relationship with precipitation in December was significant but with a negative sign $(r=-0.292, p=0.0467)$. Notably but slightly less significant were the negative correlation of May precipitation and CaL67 $(\mathrm{p}=0.071)$ and the positive correlations in November $(\mathrm{p}=0.09)$. For temperatures, maxima in May were positively and significantly correlated with CaL67 $(r=0.294, p=0.045)$, whereas minima showed significant relationships in September and December with values of $p=0.068$ and $p=0.096$, respectively. Over the 1957-2002 interval, the relationships between calcite and climate variables became weaker relative to the previous subinterval. December precipitation continued to be negatively correlated with CaL67 $(r=-0.248, p=0.096)$, the significant effect of precipitation in March disappeared, and precipitation in February became almost significant with a negative effect $(\mathrm{r}=$ $0.268, \mathrm{p}=0.071)$. With respect to temperatures, no significant relationship was observed, and only the minimum temperatures in May showed an almost significant effect, $r=0.249$ and $p=$ 0.095 .

\subsection{Time lagged cross correlation function between CaL67 and the climatic variables}

We further searched for significant relationships between the CaL67 series and climatic variables by using the cross-correlation function (CCF). This technique compares how similar two time series are by successively shifting one series over the other for positive $(+\mathrm{k})$ and negative $(-\mathrm{k})$ lags and computes correlation coefficient values between both series. Cxy $( \pm \mathrm{k})$ is the correlation coefficient between variable $\mathrm{X}(\mathrm{CaL} 67)$ and variable $\mathrm{Y}$ (monthly, seasonal and annual rainfall and temperatures), and $\pm \mathrm{k}$ is the time lag. Since cross-correlation coefficients for positive $\mathrm{k}$ values represent an unlikely relationship (i.e., the climate of future years will affect the thickness 
of the calcite sublayer of the current year), we focused on Cxy $(-k), k$-values $\leq 0$, which represent the association between the thickness of the calcite sublayers and the climatic variable of previous years. We computed the Cxy $(\mathrm{k})$ values between CaL67 and each of the seasonal and annual variables of temperatures and rainfall (variable $\mathrm{Y}$ ) without displacement $(\mathrm{k}=0)$ and for five displacements of the climatic series on the calcite series (Table S2). Table S2 shows the correlation coefficient values for the first $\mathrm{k}=5$ positive and negative lags of the climatic series on the calcite series. For $\mathrm{k}=0$, there are no significant correlation values; for negative $\mathrm{k}$ values, significant correlation coefficients between the calcite series and autumn precipitation of the preceding two and three years are significant. Remarkably, the CCF between calcite and autumn rainfall is positive for $\mathrm{k}=0$ and from $\mathrm{k}=-1$ to $\mathrm{k}=-4$. Likewise, the CCF between calcite and autumn rainfall shows significant values of Cxy at regular lags, $\mathrm{k}=-11, \mathrm{k}=-29$, and $\mathrm{k}=-34$ (Fig. 4).

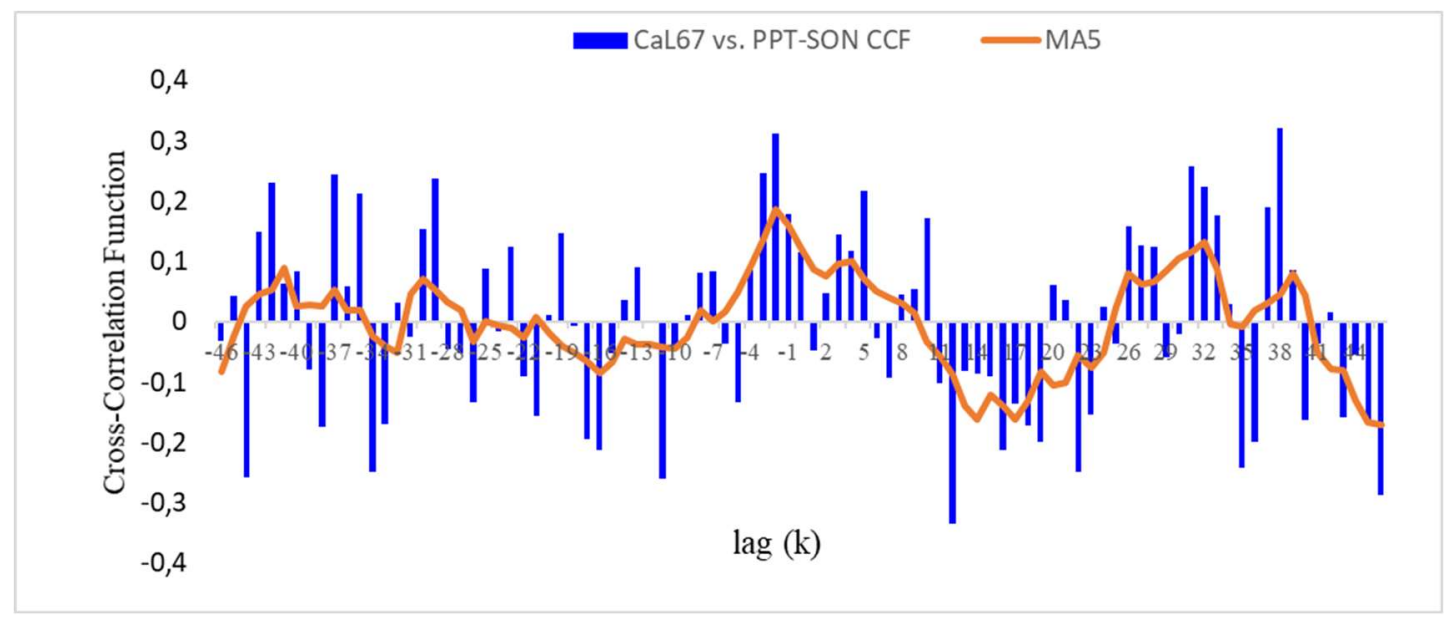

Figure 4.- Cross-correlation coefficients (bars) between the calcite series, CaL67, and autumn precipitation, PPT-SON (September, October, and November). PPT-SON is the leading series. Interval of analysis is 1910-2002. The continuous line is a moving average smoothing of five years (MA5) to highlight the synchronicity between the two series at low frequencies. 


\subsection{Correlations between CaL67 and climate variables using moving averages}

The results obtained thus far suggest that the sensitivity of CaL67 to climate is low at high frequencies but could be high at lower frequencies. To determine at which frequencies the highest synchrony between CaL67 and the climatic variables occurred, we first smoothed the series using moving averages from 3 to 11 years. Then, correlation and spectral analyses were carried out. The highest values of the correlation coefficient between CaL67 and the smoothed climatic series were obtained for windows greater than five years (Fig. S1). In contrast, as expected, not all climatic variables increased their correlations with Cal67 when increasing the size of the window. Interestingly, the highest and most significant correlation coefficients were achieved with the series corresponding to autumn precipitation (PPT-SON).

\subsection{Spectral analysis of CaL67 and climatic variables}

For the common time interval 1910-2002, we performed spectral analysis of the working series to identify their characteristic frequencies/periods of oscillation and to detect any synchrony (coherence) among CaL67 and the climate series at seasonal and annual resolutions.

The results show significant oscillation frequencies for different periods (Table S3). The table does not provide information for periods of two and three years because they have no interpretation since the sequences of random numbers also present them. The significant periods of CaL67 of the 1910-2002 interval turned out to be significant for the 1500-2002 interval as well. CaL67, autumn precipitation and spring minimum temperatures coincide in the oscillation periods of 5.69 and 5.57 years, but only the frequency spectrum of autumn precipitation exhibited global significance $(\mathrm{p}<0.05)$ with the period of CaL67 (Fig. 5). 


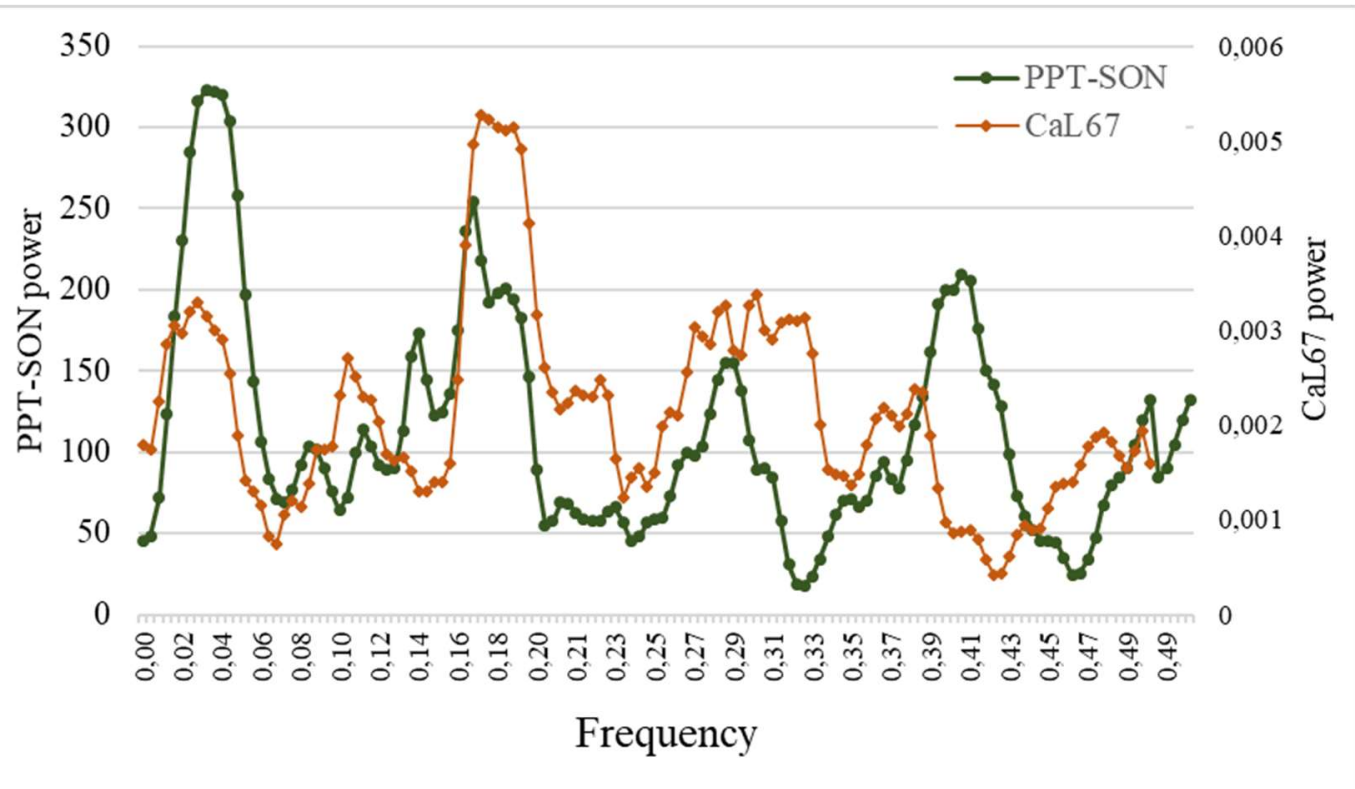

Figure 5.- Comparison of the periodograms of the calcite sublayer thickness series, CaL67, and of the autumn precipitation, PTT-SON. Period 1910-2002.

\subsection{Reconstruction of autumn precipitation}

The results obtained from the previous analyses reveal that the relationships between CaL67 and the studied climate variables were very weak at high frequencies but stronger at medium and low frequency. Thus, from the obtained results (Fig. 4, Table S2), we checked for the significance and stability of the autumn precipitation signal (PPT-SON) from the lagged CaL67 series $(\mathrm{t}=-1$, $-2,-3,-4)$ and the mean series of CaL67 from $\mathrm{t}=0$ to $\mathrm{t}=-4\left(\mathrm{CaL} 67_{\text {mean0-4}}\right)$. Correlation coefficients between those series of CaL67 and PPT-SON show that the strongest precipitation signal is achieved by de the mean series, CaL67 mean0-4 (Table 1); moreover, the climatic signal is significant and is maintained over the two sub periods, which this is not the case for the rest of the relationships when considering individual series (see also Fig. 6). To account for the effect of autocorrelation of the series and correct the p-values we used program CorrelWindows (MaciasFauria et al., 2012). 
Table 1. Results of the correlation between autumn precipitation (PPT-SON) and calcite series without displacement (CaL67-0), with displacements of 1 to 4 years and with the mean of the previous series (see Fig. 4).

\begin{tabular}{|c|c|c|c|c|c|c|}
\hline & \multicolumn{2}{|c|}{ 1910-2002 } & \multicolumn{2}{|c|}{$1910-1956$} & \multicolumn{2}{|c|}{$1957-2002$} \\
\hline & r-values & $p$-values & r-values & $p$-values & r-values & $p$-values \\
\hline CaL67-0 & 0,115 & 0,351 & 0,214 & 0,149 & 0,006 & 0,970 \\
\hline CaL67-1 & 0,177 & 0,147 & 0,199 & 0,179 & 0,131 & 0,384 \\
\hline CaL67-2 & 0,309 & 0,012 & 0,133 & 0,375 & 0,416 & 0,004 \\
\hline CaL67-3 & 0,252 & 0,038 & 0,192 & 0,197 & 0,277 & 0,062 \\
\hline CaL67-4 & 0,069 & 0,585 & 0,086 & 0,564 & 0,035 & 0,815 \\
\hline CaL67 $7_{\text {mean0-4 }}$ & 0,394 & 0,003 & 0,420 & 0,004 & 0,375 & 0,010 \\
\hline
\end{tabular}

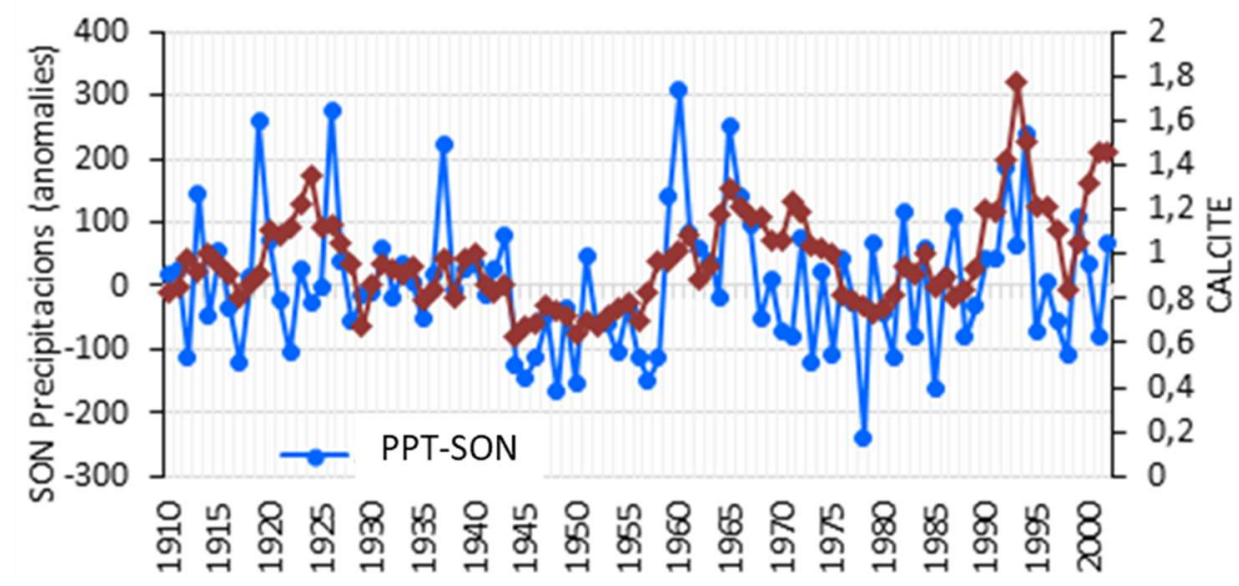

Fig. 6. A) Joint time evolution of autumn precipitations (PPT-SON) and the calcite mean width (mm) series CaL67mean0-4. 
We reconstructed the autumn precipitation (PPT-SON) for the period 1500-2002 CE (Fig. 7A and B) from the mean calcite series, CaL67mean0-4. The results of the reconstruction are given in Table 2 and determine that the model for the transfer function is considered appropriate to carry out a robust reconstruction of SON precipitation since the statistical parameters of the cross-calibration verification, i.e., R2, RE and CE are significant. The model of the transfer function we obtained is:

$\mathrm{Y}=191.848 \mathrm{X}-183.597 \quad\left(\mathrm{R}^{2}=0.155, \mathrm{p}\right.$ value $\left.=0.0020\right)$

where Y, the predictand, was the series of autumn precipitation for September, October, and November (PPT-SON) and X, the predictor, the series of calcite CaL67 mean 0-4.

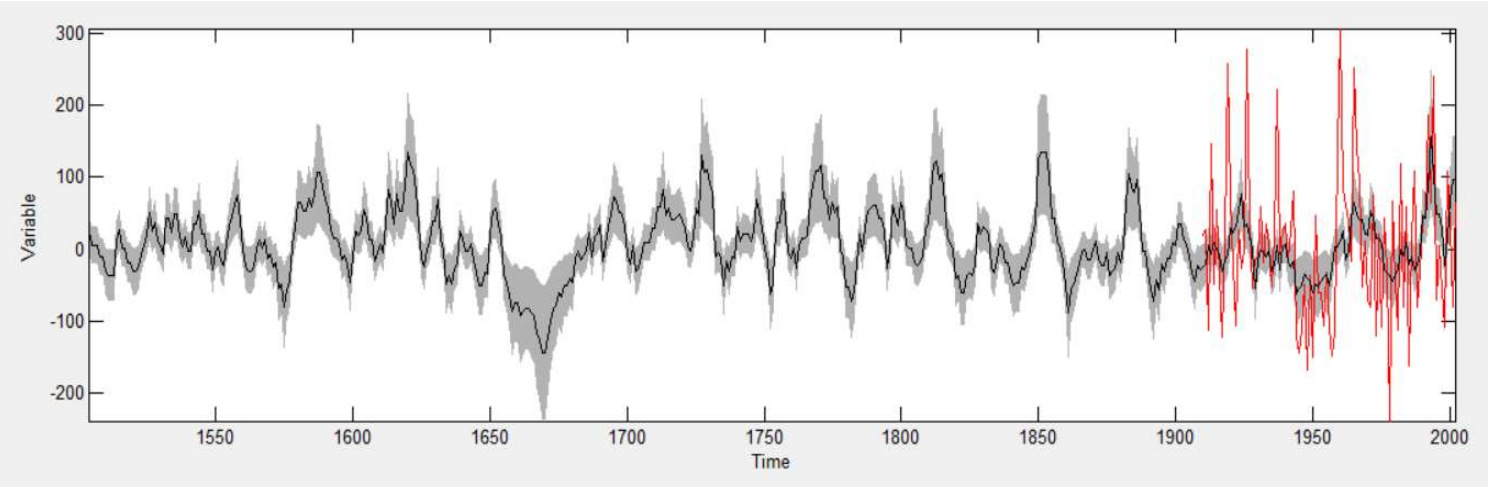

Figure 7.- Reconstruction of autumn precipitation PPT-SON (black line) using the CaL 7 mean $0-4$ series from of Lake Montcortès (1504-2002) and the autumn instrumental record (red line) of PPT-SON from the Central Pyrenees (period 1910-2002). Grey shaded area: 99\% confidence interval of the reconstruction using Ebisuzaki’s approach (see Methods).

Table 2. Transfer function model and values of the parameters related to the reconstruction of PPT-SON for the period 1910-2002 and to the calibration-verification periods, 1910-1956 and 1957-2002. Cross calibration/verification statistics tests, squared Pearson Correlation 
Coefficients (R2, r2), Reduction of Error (RE) and Coefficient of Error (CE) are significant. The values of their $95 \%$ and $99 \%$ significance thresholds are given between brackets.

\begin{tabular}{|c|}
\hline Full period: $1504-2002$. \\
\hline Full calibration period: $1910-2002$. \\
\hline Calibration period: $1910-1956$. \\
\hline Verification period: $1957-2002$. \\
\hline Monte Carlo count: 10000 \\
\hline Procedure to generate surrogate time series: Ebizusaki \\
\hline Model coefficients (full calibration period): \\
\hline PPT-SON $=+191.8481 * X-183.5968$ \\
\hline $\begin{array}{l}\text { Full calibration period: } \mathrm{R}^{2}=0.155(\mathrm{p}=0.0020) \mid\left(\mathrm{R}_{-}^{2} 95=0.080,\right. \\
\left.\mathrm{R}^{2} \text { 99 }=0.120\right)\end{array}$ \\
\hline $\begin{array}{l}\text { Cross calibration/verification tests prior to computing the } \\
\text { reconstruction: }\end{array}$ \\
\hline $\mathrm{RE}=0.107(\mathrm{p}=0.0252) \mid\left(\mathrm{RE} \_95=0.080, \mathrm{RE}\right.$ 99=0.145) \\
\hline $\mathrm{CE}=0.078(\mathrm{p}=0.0221) \mid\left(\mathrm{CE} \_95=0.046, \mathrm{CE} \_99=0.106\right)$ \\
\hline Cal. period: $\mathrm{R}^{2}=0.177(\mathrm{p}=0.0192) \mid\left(\mathrm{R}^{2} \_95=0.133, \mathrm{R}^{2} \_99=0.204\right)$ \\
\hline Ver. period: $\mathrm{r}^{2}=0.141(\mathrm{p}=0.0464) \mid\left(\mathrm{r}^{2}-95=0.137, \mathrm{r}^{2} 99=0.214\right)$ \\
\hline $\mathrm{RE}=0.183(\mathrm{p}=0.0028) \mid\left(\mathrm{RE} \_95=0.079, \mathrm{RE} \_99=0.136\right)$ \\
\hline $\mathrm{CE}=0.146(\mathrm{p}=0.0021) \mid\left(\mathrm{CE} \_95=0.046, \mathrm{CE} \_99=0.097\right)$ \\
\hline Cal. period: $\mathrm{R}^{2}=0.141(\mathrm{p}=0.0464) \mid\left(\mathrm{R}^{2} \_95=0.137, \mathrm{R}^{2} \_99=0.214\right)$ \\
\hline Ver. period: $\mathrm{r}^{2}=0.177(\mathrm{p}=0.0192) \mid\left(\mathrm{r}^{2}-95=0.133, \mathrm{r}^{2}-99=0.204\right)$ \\
\hline
\end{tabular}

The reconstructed autumn precipitation, PPT-SON, is depicted in Fig. 7A. Compared to the other reconstructions based on different smoothing or individual series of calcite as predictors (Table 1), this reconstruction (Fig. 7A) provides the best results because (1) the climatic signal is maintained for the calibration-verification periods and (2) it better matches the variability of the original SON series at high, medium, and low frequencies. Indeed, the spectral 
coherence analysis (Fig. 7B) shows a high and significant synchrony at medium and large frequencies of variability, which is similar to the periodogram depicted in Fig. 5.

\subsection{PPT-SON forcing: relationship with teleconnection patterns}

It has been demonstrated that low-frequency Atlantic and European atmospheric modes affect precipitation and drought patterns on the IP at different spatial and temporal scales, with the North Atlantic Oscillation (NAO), El Niño Southern Oscillation (ENSO), Mediterranean Oscillation (MO), Western Mediterranean Oscillation (WEMO) (Gonzalez-Hidalgo et al., 2009; Martin-Vide and Lopez-Bustins, 2006; Rodriguez-Puebla et al., 1998) being the most important modes. In particular, a relationship between precipitation, extreme events and WEMO based on detrital layers has been described in Montcortès (Corella et al., 2016). It seemed therefore reasonable to search for likely correlations between the predicted precipitation series PPT-SON and the NAO, SOI, and WEMO indices. We therefore calculated cross correlations of PPT-SON with these main indices, known to affect the IP. For this, we chose the reconstructed NAO index back to 1504 (Luterbacher et al., 1999, 2002) and the NAO index from 1822 (Jones et al., 1997). For the Southern Oscillation, we applied the SOI index since 1822 (Ropelewsky and Jones, 1987) and, for the Western Mediterranean Oscillation, the WeMO index since 1821 (MartinVide and Lopez-Bustins, 2006). We chose the autumn seasonal series of the indices and, except in the case of the SOI, also the winter, spring, and summer series since the SOI index has a delayed influence on precipitation of the IP. The series of indices were correlated on an annual basis and with an 11-year Gaussian filter. Positive lags were ignored because the rationale that precipitation influences the indices is senseless. Only filtering the summer SOI index yielded meaningful results with a maximum negative correlation of $>0.3$ with a lag of 0 (Fig. 8). The 
calculated correlation coefficients of the WEMO index were moderately high between 1950 and 1977 (-0.51) and thereafter dropped slightly, -0.38 for the 1920-1997 interval.

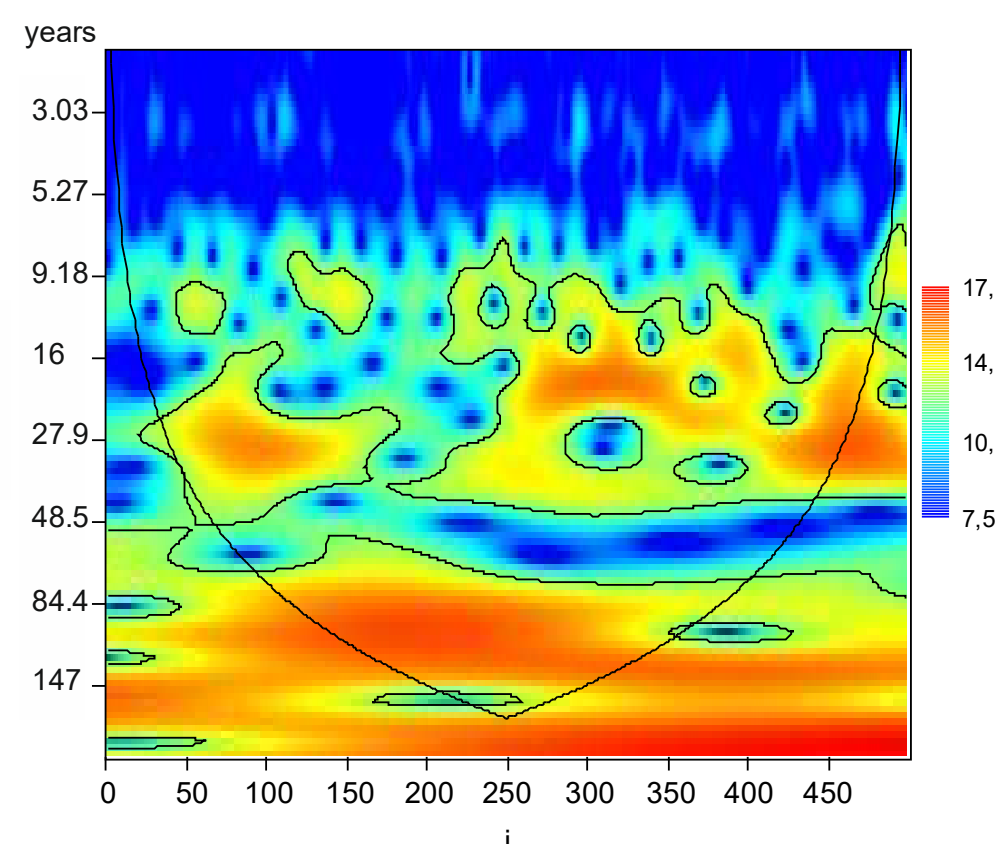

Figure 8.- Wavelet power spectra of the reconstructed autumn precipitation signals. Contours specify the significance level corresponding to $p=0.05$. The cone of influence" signalises the region where boundary effects on power indices are present. Y: periods (years). X: time (years).

To further assess the likely occurrence of other low-frequency (LF) and high-frequency (HF) forcings of the Mediterranean climate on reconstructed autumn precipitation since 1500 CE, we used Morlet's continuous wavelet transform (CWT) analysis (Torrence and Compo, 1998; Zhang and Moore, 2011), which enables the identification of both the dominant modes of variability and how these modes shift with time periodicities. The results are shown in a scalogram (Fig. 8). The top displays a more resolved, fine-grained view, while the bottom represents a smoothed view of longer trends. The region inside the cone of influence contains 
reliable values not affected by boundary conditions, and significance levels $p=0.05$ are plotted contours. Two significant low-frequency spectral bands can be observed. The first band is centred around a 30-years period and is significant over approximately 350 years $(60 \%)$, i.e., from 1570 to 1923 . The second and stronger band is centred at the 80 -year period with confident values, i.e., from 1600 to 1850 (250 years).

\section{DISCUSSION}

\subsection{The temporal structure and information of the calcite record}

The calcite sublayer thickness series used in this study represents an exceptional annual record of ecological and biogeochemical processes operating under the influence of Mediterranean climate in Lake Montcortès, between 1500 and 2002 CE. Our main objective was to determine which climatic signals were recorded in the calcite and to perform their reconstruction. The detailed study of the temporal structure of the calcite series showed a long-term trend that ran through the entire series due to the compaction processes of the sediment with time (Fig. 2). This trend was removed with a low-pass filter (67\% of the series length cubic smoothing spline) to obtain a stationary series, CaL67, (Fig. 3) of constant mean, to preserve the variance and thus be able to uncover the existence sharper periodic oscillations, without the red noise generated by the trend of the series. The results of the spectral analysis revealed significant periodic oscillation frequencies of the CaL67 series, with periods of circa 38, 16, 11 years approx. (Table S1, Fig. 5) and probably related to general atmospheric circulation phenomena (Figs. 7B and 8; section 5.3). Other shorter period oscillation frequencies (7, 5, 4 years) are difficult to explain and may be due to more local atmospheric phenomena. 


\subsection{The reconstructed autumn precipitations changes}

We obtained a reliable reconstruction of autumn precipitation, PPT-SON, (Fig. 7) for the Central Pyrenees with annual resolution, based on a combination of the CaL67 series with itself, the CaL67mean0-4 series. This series is the average obtained from the calcite series without displacement plus the calcite series lagged one to four years. The reason for doing this is given by the effect (positive correlations) that autumn precipitation has on the thickness of the calcite in the current year and up to 4 years earlier (Fig. 4). It should be noted that no other climatic variable did show persistent and significant effects on the thickness of the calcite (Table S2) and that the CaLmean0-4 calcite series is the only one that shows a stable climatic signal over the calibration-verification subperiods (Table 1, Fig. 6).

The obtained transfer function model explains $15.5 \%\left(\mathrm{R}^{2}\right.$-value for the full calibration period, Table 2) of the September to November precipitation variability and is statistically robust, since the verification tests of the climate signal are significant (Table 2, Fig. 6). In addition to the complex nature of atmospheric circulation, which sets major limits on precipitation predictability in many regions, in our case, some additional causes may account for the low variance explained by the transfer function model. One cause relies on the type of proxy record since the thickness of the calcite sublayers integrates several processes at the ecosystem lake level that may affect the climatic signal. A former pilot study with traps in Montcortès (Trapote et al., 2018b) revealed that calcite crystals develop in the water column under conditions of calcite saturation, higher $\mathrm{pH}$, and productivity conditions. Fluxes of authigenic calcite deposition to the sediment were highest from summer to fall and lowest from winter to spring. A likely explanation for the relation between autumn rainfall and calcite sublayer thickness could be that in hydrologically closed systems such as Lake Montcortès, interannual 
precipitation variability controls groundwater discharge. Autumn water renewal contributes significantly to the restoration of water column calcium concentrations before summer calcium carbonate precipitation events, as seen in similar lake settings (i.e., Lake La Cruz; Romero-Viana et al., 2011). Another potential relationship between autumn precipitation and calcite sublayers could be related to the increase in carbonate and additional nutrients from the catchment during heavy rainfalls, enhancing biogenic calcite precipitation pulses during summer, as seen in other lakes (e.g., Lake Baldeggersee; Lotter and Birks, 1997). Additionally, 50\% of the extreme precipitation events at Montcortès happened in autumn (Corella et al., 2016). A cause for the low amount of variance explained by some model using varves may be the uncertainty associated with the method of dating, but in this case no interpolation of sublayers has been done for the correlation period of the $20^{\text {th }}$ century (Corella et al., 2014). Additionally, the correlation coefficients were corrected for the autocorrelation of the series, which decreases the number of degrees of freedom, thus lowering the correlation values. Even so, the use of the appropriate methodology made it possible to show that the climatic signal indeed was captured in the annual calcite sublayers. Therefore, they could be used as a proxy to reconstruct climate, i.e., autumn precipitation in this study. Autumn precipitation is a distinct feature of eastern Iberia (LopezBustins and Lemus-Canovas, 2020). Typically, Mediterranean precipitation shows rainy winters and dry summers, and this regime is associated with westerly atmospheric circulation in winter and the subtropical anticyclone belt in summer. However, in the eastern Iberian region, precipitation maxima occur in autumn and spring and are the result of the complex orography of the IP (De Luis et al., 2009, 2011). At a smaller spatial scale, the seasonal pluviometric regime of the north-eastern area (e.g., Catalonia) has amazing variability and shows eight different spatial ordinations within the possible seasonal permutations (de Castro et al., 2005). 
The variations in the calcite sublayer width were also influenced by factors that overrode, or were equally important to the annual amount of calcite deposition linked with autumn precipitation. In fact, they reflected the supra-annual variability of long-term precipitation of this sector of the IP. Presumably, long-term autumn precipitation and varve calcite width are indirectly linked through variations in the supplies of external calcite and phosphorus $(\mathrm{P})$ to the lake via runoff from the catchment. Variations in the external supply of $\mathrm{P}$ in autumn may affect phytoplankton growth and photosynthesis of the next spring and therefore biogenic calcite deposition in sublayers during the next summer-autumn, especially in meromictic years when internal P turnover is difficult. In such situations of a limited supply of internal P, phytoplankton mainly rely on external P loading. Such supra-annual effects would become clearly visible only in years when precipitation events had been significantly stronger or less frequent as the annual mean. Prolonged periods or extreme periods of drought may also have a significant effect on calcite varve width by temporarily shortcutting the P supply to the lake via runoff. Conversely, stochastic torrential rains can supply extra calcite and $\mathrm{P}$ by triggering episodes of higher-than annual average inputs of allochthonous $\mathrm{P}$ to the lake, adding more variability. A further difficulty for the climate signal to be clearly captured is the fact that in karstic lakes such as L. Montcortès, P can easily be retained in the form of apatite minerals in the lake's sediment, contributing to the calcite sublayer and becoming temporarily unavailable for primary producers (López Laseras, 1991). Finally, increases in the supply of $P$ by soil erosion due to human activities may have affected the natural patterns and effects of precipitation-driven $\mathrm{P}$ to the lake, especially during the 18th and 19th centuries, when human activity was highest (see Section 2). 


\subsection{Comparison with other proxies and meteorological records of the IP}

The autumn precipitation predicted by our model starts when the Little Ice Age (LIA) already impacted the mountains of the IP and most of Europe was under the effect of the Spörer solar minimum (Oliva et al., 2018). At the IP, the LIA not only brought frequent shifts between warm and cold conditions but also marked spatial and temporal variability in precipitation (Alcoforado et al., 2000; Rodrigo and Barriendos, 2008; Rodrigo et al., 1999) with severe droughts, floods, and cold/heat waves with significant spatiotemporal variation. This changing climate pattern started around $1300 \mathrm{CE}$ and lasted until approximately $1850 \mathrm{CE}$. (Oliva et al., 2018 and literature therein).

The retropredicted CaL67mean0-4 time series suggests that the $17^{\text {th }}$ century was comparatively the least rainy since $1500 \mathrm{CE}$, with a mean precipitation anomaly value of -6.74 $\mathrm{mm}(\sigma=5.89 \mathrm{~mm})$ and a minimum of $-144.5 \mathrm{~mm}$ in $1670 \mathrm{CE}$. No instrumental time series exists that recorded the pluviometric features of the $17^{\text {th }}$ century, which in our study comprises the driest intervals (1655-1686 CE) of the entire period of study. These dry intervals were followed by a rapid return of precipitation events. The most negative precipitation anomalies $(<-144 \mathrm{~mm})$ coincided with the Maunder sunspot minimum (1645-1715 CE) (Eddy, 1976). These results are broadly consistent with the signal yielded by other drought and hydroclimatic proxies, both locally and regionally and over several intervals. For instance, palynological records indicate that weeds such as Thypha sp. growing on the shoreline of Lake Montcortès expanded lakeward between 1632 and $1686 \mathrm{CE}$, probably due to shrinkage of the lake surface (Trapote et al., 2018a). This weed is usually one of the first species to colonize the drying terrains of lagoons and swamps. There is also partial coincidence with macrofossil hydroclimatic indices from the northwestern IP, which revealed a general decrease in the abundance of wetness indicator species 
and a slight reduction in peat humification, between 1610-1735 CE (Castro et al., 2020).

Additionally, tree ring records from the central IP showed that extreme negative pointer years, representing minimum growth, were much more frequent over the first half of the 17 th century and highlighted that 1645, 1946, 1950, and 1959 were dry years (Génova, 2012). On the other hand, the strong recovery of precipitation indicated by our model between 1670 and $1683 \mathrm{CE}$ is consistent with the analysis of rogation ceremonies, when a decrease in the drought index relative to mean values was identified during the late Maunder Minimum (1675-1715 CE). Documentary data provided descriptions of weather with amazing resolution (Barriendos, 1997; Domínguez-Castro et al., 2008, 2010).

Except for the $17^{\text {th }}$ century, the mean autumn precipitation anomalies of each century were all positive and averaged $10.8 \mathrm{~mm}$, with the $18^{\text {th }}$ century being slightly wetter at $24.8 \mathrm{~mm}$. Dry and wet years were identified as those with anomalies larger $(+)$ or smaller $(-)$ than one standard deviation $(47.8 \mathrm{~mm})$, and dry and wet periods were identified as those with anomalies above or below one standard deviation for more than four consecutive years. Under these criteria, the $17^{\text {th }}$ century was the driest and the $18^{\text {th }}$ century the wettest was related to the entire period of study, with frequencies of $23 \%$ dry and $29 \%$ wet years, respectively. During the 20 th century, the frequency of wetter years seemed to descend slightly, which was consistent with the periods of reduced precipitation.

According to our reconstruction, precipitation was subjected to pronounced interdecadal shifts with anomaly values fluctuating between -144 and $+155 \mathrm{~mm}$. However, no linear increasing or decreasing trend could be identified (slope $=0.0045)$, nor was any of the five centuries clearly differentiated by any particularly notorious precipitation pattern, in addition to the dry period observed between $1655 \mathrm{CE}$ and 1686 (Fig. 10). This latter period also coincides 
with a decrease in reconstructed heavy rainfall events ( $>90 \mathrm{~mm}$ maximum daily precipitation) occurring between 1640-1680 CE (Corella et al., 2014). The reconstructed CaL67mean0-4 did not reflect periods of extreme precipitation frequency and intensity, whereas Corella et al. (2014) reported that a significant increase in extreme precipitation frequency and intensity occurred during the second half of the $19^{\text {th }}$ century (Corella et al., 2014). Several reasons for this discrepancy can be suggested. First, because the CaL67mean0-4 series is smoothed and second, extreme events were identified from the presence of detrital layers and turbidites interbedded within the varved sediment record of Lake Montcortès and not from calcite sublayers. The latter mainly reflected the calcite content in the biogenic varves (Trapote et al., 2018b). Such acute rainfall episodes may have abruptly dragged nutrients into the lake as well as amounts of particles that may have muddied the water, thus counteracting any prolonged enrichment effect on pelagic primary producers. An alternative explanation could be related to the increase in turbidite events recorded during this period that might have resulted in micro-erosion of the underlying $\mathrm{CaL}$. The micro-erosion in those sublayers might have derived a reduction in $\mathrm{CaL}$ thicknesses and thus lower "artificial" values of the reconstructed autumn precipitation.

The reconstructed series was consistent at the regional level. Despite the different geographic settings (coast versus mountain), we compared the predicted autumn precipitation CaL67mean0-4 with the nearest and longest instrumental precipitation series of the IP, i.e., the one of Barcelona (BCN) between CE 1786 and 2014 (Prohom et al., 2015) (Figs. S2 and S3). The CaL67mean0-4 series matched relatively well with the BCN series over the 20th century (r: $0.594, p)$, despite an interval of approximately 50 years between 1786 and $1840 \mathrm{CE}$ where both series ran with opposite sign. This mismatch may be due to non-natural shifts in calcite deposition and/or to imprecisions in the reconstruction of the Barcelona pluviometry series. On 
the one hand, this period coincides with an increase in Cannabis pollen content in the sediment of Lake Montcortès, with a remarkable peak in ca. $1838 \mathrm{CE}$ and suggests active cultivation and treatment of Cannabis fibres around the lake (Trapote et al., 2018a). This activity may have triggered soil erosion and thereby disturbed calcite deposition. On the other hand, the interval from $1780 \mathrm{CE}$ to $1827 \mathrm{CE}$ corresponds to the first documentary source obtained from Dr. Francesc Salvà, preserved in original handwritten tables made by the observer himself, and containing several uncertainties in the units and instruments of measurement (Prohom et al., 2015).

The correlation between the series of BCN and the autumn precipitation of the central Pyrenees over their period of overlap of instrumental measurements was high and significant (r: 0.801, $\mathrm{p}=0.0001$ ) (Fig. S3). The CaL67mean0-4 series was also correlated with the regional autumn precipitation series of the central Pyrenees and yielded a significant correlation value of $0.598(\mathrm{p}=0.0001)$. However, a notable discrepancy was the huge anomaly of $+155.6 \mathrm{~mm}$ between 1991 and 1996 that was not reflected by either of the two instrumental series. This suggested that the effect of precipitation at a smaller scale could have been relatively important at times. In fact, over the second half of the 20th century, maximum autumn precipitation in the IP was located along the Pyrenees (de Luis et al., 2010). Particularly rainy years were 1992, with an average value of precipitation of $23.2 \%$, which is higher than that of the reference period (1961-1990), 1979 and 1996 (Serrano-Muela et al., 2013;OPCC-CTP, 2018). Exceptions were also the extreme rainfall events recorded at various meteorological stations in the central Pyrenees in November 1982 with more than $200 \mathrm{~mm}$ over 3 days or the event of more than 220 mm in 125 hours in August 1996. Both episodes generated destructive floods in the main Pyrenean rivers (García-Ruiz et al., 1996). 


\subsection{Low frequency climatic oscillations}

The instrumental precipitation patterns in central southern Pyrenees were L. Montcortès is located show low correlation with the North Atlantic Oscillation (NAO) (Muñoz-Díaz and Rodrigo, 2005) and the Western Mediterranean Oscillation (WEMO) (Martin-Vide and LopezBustins, 2006), which may account for the weak correlation of the reconstructed precipitation with those indices. The influence of the NAO decreases from south to north and from west to the east in the IP, with low correlations with this index corresponding to this sector. The WEMO also shows a very robust relationship with precipitation in the central Pyrenees. On the other hand, a certain inflection is detected during autumn months depending on the phases of the Southern Oscillation (Martin-Vide and Lopez-Bustins, 2006; Muñoz-Díaz and Rodrigo, 2005; Trigo et al., 2004). In these cases, although the ENSO signal is not very strong, it is more consistent than for the two previous indices.

Morlet's wavelet analysis identified significant multidecadal, 30- to 80-year variability in the CaL67mean0-4 series over almost all the studied time frames and vanished in the second half of the 20th century, coinciding with the current climate warming.

The time span of our reconstruction is long enough to detect the likely existence of a sustained oscillation in rainfall, and in fact, the encountered frequencies seem to be consistent with the Atlantic Multidecadal Oscillation (AMO) mode, first described by Schlesinger and Ramankutty (1994) and further explored by others. According to different authors, the AMO seems to be dominated by distinct time scales: 60-80 year periods (Enfield et al., 2001;

Schlesinger and Ramankutty, 1994), 20-30 years associated mainly with the Atlantic Meridional Overturning Circulation, 50-70 years related to the atmospheric exchange between the Atlantic 
and the Arctic Ocean, and multidecadal 40-70 years, with a marked statistical significance for the 70-year periodicity (see Abrantes et al., 2011 and literature therein).

The AMO is a prominent climate pattern that impacts the North Atlantic Ocean and surrounding Northern Hemisphere continents (Knight et al., 2006; Sutton and Hodson, 2005; Zhang and Delworth, 2006). It has been defined as the detrended, 10-year running mean of North Atlantic $\left(0^{\circ}-60^{\circ} \mathrm{N}\right)$ sea surface temperature (SST) anomalies (Alexander et al., 2014). Abrantes et al. (2011) found a connection between Atlantic oceanic circulation and AMO (74-year cycling) along the western Iberian margin that had an important incidence on sea surface temperature and precipitation, mainly between $900 \mathrm{CE}$ and $1200 \mathrm{CE}$ in the north and after 1580 $\mathrm{CE}$ in the south, although the signal disappeared after $1850 \mathrm{CE}$. AMO's influence at decadal scales has also been noticed in the Mediterranean, and its variability has been suggested to be transmitted from the Atlantic Ocean to the Mediterranean Sea via atmospheric processes (Mariotti and Dell'Aquila, 2012; Pisano et al., 2020).

The likely effect of AMO on autumn precipitation of the Pyrenees is brought hereby as a possibility, but its verification is beyond the scope of this work and deserves further research and, especially, more time course given its relatively low frequency, if compared with other teleconnections. Along with the effect of AMO, interactions with other concurrent teleconnections are crucial to explain present and past precipitation patterns.

\subsection{Comparison with other reconstructions of the Mediterranean context}

The Mediterranean region is located in a transitional zone that is affected by mid-latitude and tropical climate processes and has notable regional-scale variations in the hydrological cycle. Heterogeneity and uncertainties also arise from the different nature and timespan of the proxies 
used, their uneven spatial and temporal resolution and the climatic phenomena they are related to. Reconstructions of precipitation are scarce, and studies on variations in the hydrological cycle have mainly focused on paleoflood and extreme events (Corella et al., 2021; Luterbacher et al., 2012). Furthermore, humans have strongly altered the Mediterranean landscape over the last millennia, blurring many climatic signals that may have allowed for more extended climatic reconstructions (see Rick et al., 2020 and literature therein). Montcortès is not an exception; the varved sediments of the lake show evidence of humans in the landscape over the last ca. 3000 years, since the Bronze Age (Rull et al., 2021b). In contrast, long-term precipitation climate series are available going back to 360 years (Luterbacher et al., 2012). Consistent with the estimations of our model, the 14 longest precipitation instrumental series of the Western Mediterranean regions covering the last 300 years from 1797 showed repeated swings between rainy and dry periods, with no specific trends. This pattern lasted until the most recent decades, when some more marked departures from the average were observable. It is noteworthy that correlations between the various Mediterranean subareas were generally not significant or almost uncorrelated (Camuffo et al., 2013).

On the IP, climatic differences between northern and southern regions seem to have determined divergent responses of lakes to climate over the last 2000 years, as revealed by studies based on geochemical and biological analyses and centennial resolution. However, paleoprecipitation reconstructions are still scarce and even more scarce at short time scales, with references to variations in environmental humidity or precipitation/evaporation patterns being the most common hydroclimatic descriptions. This makes it difficult to attain a general paleoclimatic overview. Despite this fact and considering that the Mediterranean rainy season is between October and March (Xoplaki et al., 2004), we made some general comparisons to contrast the 
regional coherence of our model. For example, when compared with the previous period (1150$1300 \mathrm{CE}$ ), the nearby karstic lake Estanya (Pre-Pyrenenan range) shows a general trend towards higher water levels and more diluted waters between 1300-1888 CE, based on sedimentological and pollen data (Morellón et al., 2012; Riera et al., 2004). Nonetheless, this period was intermingled by wet and dry intervals, attesting to a complex internal palaeohydrological structure, and was coeval with an increase in human activities (Morellón et al., 2009, 2012, Riera et al., 2004). This is the interval where our precipitation model indicates the driest episode (1675-1715 CE) of the period of study, and in effect, this episode correlates with a drier phase that triggered a severe fall in water level at lake Estanya, between ca. 1580, and $1760 \mathrm{CE}$ (Riera et al., 2004). According to these authors, this event would coincide with the dry and warm period that took place between 1675 and $1750 \mathrm{CE}$, as was also recorded by tree ring width (Creus et al., 1996; Creus and Saz, 1999; Dorado Liñán et al., 2012, 2015). Furthermore, the water level in Estanya declined during the $20^{\text {th }}$ century (Morellón et al., 2012), which is consistent with the slight decrease in the frequency of wetter years detected by our CaL67mean0-4 series. In the southern IP, pollen and sedimentological data of the varved and karstic lake Zoñar recorded a humid period of approximately $1600 \mathrm{CE}$, which seems compatible with our estimations (MartínPuertas et al., 2008). Of particular interest for its similarity with Lake Montcortès is karstic Lake La Cruz, where the thickness of annual calcite laminations allowed to reconstruct winter precipitation since 1579 CE (Romero-Viana et al., 2011). Because the estimated precipitation series of Lake La Cruz represents a different climatic season, it is not directly comparable with our CaL67mean0-4 series (SON).

Shifts in the proxy records of Montcortès and Estanya seem to be opposed to some paleoclimatic records from other settings in Eastern Europe (Levant, Balkan Peninsula, Turkey) 
over the last millennium. This has been explained by the effect of a bipolar climate see-saw that has operated in the Mediterranean for approximately the last 1100 years (Koutsodendris et al., 2017; Roberts et al., 2012). For example, in southwestern Morocco, speleothem records (Brahin, 2017) indicate that the period between 1500-1640 CE was a dry phase followed by a long, humid phase with peaks at approximately $\sim 1680 \mathrm{CE}$ and 1810 . The first peak is opposed to what we found, i.e., a dry interval between 1655 and $1686 \mathrm{CE}$, although both records showed trends towards drier conditions since 1900 CE. Similarly, in the Etoliko lagoon record (Balkan Peninsula), Koutsodendris et al. (2017) found enhanced winter precipitation between 1450 and $1740 \mathrm{CE}$, as deduced from increased transport of terrestrial material into the lake sediment, in a context of vegetation scarcity and stability.

\section{CONCLUSIONS}

The reconstructed series based on calcite laminae thickness from the Montcortès varved record (PPT-SON) provides the first estimations of regional autumn precipitation shifts in the Central Pyrenees, since 1500 CE. Our results support the use of calcite sublayer width as a consistent quantitative proxy for regional precipitation. The obtained regression model (Eq. 1) allows inferring past autumn precipitation from calcium carbonate laminae thickness at annual resolution.

The predicted autumn precipitation (PPT-SON) from the combined calcite time series average CaL67mean0-4 was consistent at the regional level and able to capture the marked temporal precipitation variability that characterised the LIA period in the Central Pyrenean region until $1850 \mathrm{CE}$. It also reflects the dryer conditions that began in the $20^{\text {th }}$ century and that persisted and intensified through today. The most evident precipitation anomaly observed 
coincides with the Maunder sunspot minimum and is concurrent with inferences made from other proxies from the IP, indicating drought periods. The estimations of our model are consistent with the 14 longest precipitation instrumental series of the Western Mediterranean regions, which cover the last 300 years from $1797 \mathrm{CE}$.

Correlations between the predicted autumn precipitation time series and the main teleconnections affecting the IP -NAO, ENSO and WEMO- were rather weak. Time-frequency analysis of this nonstationary time series suggests some relationship with the AMO, which seems to account for 30 - to 80 -year period oscillations of the reconstructed autumn precipitation between the late $16^{\text {th }}$ and the early $20^{\text {th }}$ centuries. The AMO does reflect complex processes in the coupled atmosphere-ocean system of the North Atlantic. Further studies are needed to test the encountered linkage, although available instrumental SST data are short in length compared to the multidecadal timescale of the AMO.

Despite the mentioned limitation, the varved record from Lake Montcortès provided a general view of annual, decadal and supradecadal precipitation variability for the Central Pyrenees over the last 500 years, with satisfactory results. The obtained pattern is broadly consistent with the main western Mediterranean instrumental precipitation patterns and does not seem to be significantly influenced by the local effects of its mid-mountain altitudinal and topographic position.

\section{FUNDING}

Funding was granted by the Spanish Ministry of Economy and Competitivity (MINECO/FEDER) projects MONT-500, ref. CGL2012-33665; MEROMONT, CGL201785682-R; G LOBALKARST, ref. CGL2009-08145) and the Catalan University and Research 
Management Agency (AGAUR) project 2017, ref. SGR 1116). Fieldwork permits were provided by the Territorial Service of the department of Agriculture, 749 Livestock, Fishing and Natural Environment of Catalonia.

\section{REFERENCES}

Abrantes, F., Rodrigues, T., Montanari, B., Santos, C., Witt, L., Lopes, C., Voelker, A.H.L., 2011. Climate of the last millennium at the southern pole of the North Atlantic Oscillation: an inner-shelf sediment record of flooding and upwelling. Clim. Res. 48, 261-280. https://doi.org/10.3354/cr01010.

Alcoforado, M.J., Nunes, M.D.F., Garcia, J.C., Taborda, J.P., 2000. Temperature and precipitation reconstruction in southern Portugal during the late Maunder Minimum (AD 1675-1715). Holocene 10, 333-340. https://doi.org/10.1191/095968300674442959.

Alexander, M.A., Halimeda Kilbourne, K., Nye, J.A., 2014. Climate variability during warm and cold phases of the Atlantic Multidecadal Oscillation (AMO) 1871-2008. J. Mar. Syst. 133, 14-26. https://doi.org/10.1016/j.jmarsys.2013.07.017.

Amann, B., Lamoureux, S.F., Boreux, M.P., 2017. Winter temperature conditions (1670-2010) reconstructed from varved sediments, western Canadian High Arctic. Quat. Sci. Rev. 172, 1-14. https://doi.org/10.1016/j.quascirev.2017.07.013.

Amann, B., Szidat, S., Grosjean, M., 2015. A millennial-long record of warm season precipitation and flood frequency for the North-western Alps inferred from varved lake sediments: implications for the future. Quat. Sci. Rev. 115, 89-100. https://doi.org/10.1016/j.quascirev.2015.03.002. 
Barrera-Escoda, A., Cunillera, J., 2011. Climate change projections for Catalonia (NE Iberian Peninsula). Part I: regional climate modeling. Tethys 8, 75-87. https://doi.org/10.3369/tethys.2011.8.08.

Barriendos, M., 1997. Climatic variations in the Iberian Peninsula during the late Maunder Minimum (AD 1675-1715): an analysis of data from rogation ceremonies. Holocene 7, 105-111. https://doi.org/10.1177/095968369700700110.

Besonen, M.R., Patridge, W., Bradley, R.S., Francus, P., Stoner, J.S., Abbott, M.B., 2008. A record of climate over the last millennium based on varved lake sediments from the Canadian High Arctic. Holocene 18, 169-180. https://doi.org/10.1177/0959683607085607.

Brauer, A., Casanova, J., 2001. Chronology and depositional processes of the laminated sediment record from Lac d'Annecy, French Alps. J. Paleolimnol. 25, 163-177. https://doi.org/10.1023/A:1008136029735.

Brahim Y.A., Cheng, H., Sifeddine, A, Wassenburg J.A., Cruz, F.W, Khodri; M, Sha L., PérezZanón N., Beraaouz E.A., Apaéstegui, J., Guyot, J.L., Klaus Peter Jochum, K.P., Bouchaou, L., 2017. Speleothem records decadal to multidecadal hydroclimate variations in southwestern Morocco during the last millennium. Earth Planet. Sci. Lett. 476, 1-10

Brogli, R., Sørland, S.L., Kröner, N., Schär, C., 2019. Causes of future Mediterranean precipitation decline depend on the season. Environ. Res. Lett. 14, 114017. https://doi.org/10.1088/1748-9326/ab4438.

Calbó, J., Sánchez-Lorenzo, A., Cunillera, J., Barrera-Escoda, A., 2010. Projeccions i Escenaris futurs, in: Llebot, J.E. (Ed.), 2n Informe sobre el Canvi Climàtic a Catalunya, Grup 
d'Experts en Canvi Climàtic de Catalunya. Generalitat de Catalunya i Institut d'Estudis Catalans, Barcelona, pp. 183-239.

Campins, J., Genovés, A., Jansa, A., Guijarro, J.A., Ramis, C., 2000. A catalogue and a classification of surface cyclones for the Western Mediterranean. Int. J. Climatol. 20, 969-984. https://doi.org/10.1002/1097-0088(200007)20:9<969::aid-joc519>3.0.co;2-4.

Camuffo, D., Bertolin, C., Diodato, N., Cocheo, C., Barriendos, M., Dominguez-Castro, F., Garnier, E., Alcoforado, M.J., Nunes, M.F., 2013. Western Mediterranean precipitation over the last 300 years from instrumental observations. Clim. Change 117, 85-101. https://doi.org/10.1007/s10584-012-0539-9.

Castro, D., Souto, M., Fraga, M.I., García-Rodeja, E., Pérez-Díaz, S., López Sáez, J.A., Pontevedra-Pombal, X., 2020. High-resolution patterns of palaeoenvironmental changes during the Little Ice Age and the Medieval Climate Anomaly in the northwestern Iberian Peninsula. Geosci. Front. 11, 1461-1475. https://doi.org/10.1016/j.gsf.2020.05.015.

Corella, J.P., Benito, G., Monteoliva, A.P., Sigro, J., Calle, M., Valero-Garcés, B.L., Stefanova, V., Rico, E., Favre, A.C., Wilhelm, B., 2021. A 1400-years flood frequency reconstruction for the Basque country (N Spain): integrating geological, historical and instrumental datasets. Quat. Sci. Rev. 262, 106963. https://doi.org/10.1016/j.quascirev.2021.106963.

Corella, J.P., Benito, G., Rodriguez-Lloveras, X., Brauer, A., Valero-Garcés, B.L., 2014. Annually-resolved lake record of extreme hydro-meteorological events since AD 1347 in NE Iberian Peninsula. Quat. Sci. Rev. 93, 77-90. https://doi.org/10.1016/j.quascirev.2014.03.020. 
Corella, J.P., Benito, G., Wilhelm, B., Montoya, E., Rull, V., Vegas-Vilarrúbia, T., ValeroGarcés, B.L., 2019. A millennium-long perspective of flood-related seasonal sediment yield in Mediterranean watersheds. Glob. Planet. Change 177, 127-140. https://doi.org/10.1016/j.gloplacha.2019.03.016.

Corella, J.P., Brauer, A., Mangili, C., Rull, V., Vegas-Vilarrúbia, T., Morellón, M., ValeroGarcés, B.L., 2012. The 1.5-ka varved record of Lake Montcortès (southern Pyrenees, NE Spain). Quat. Res. 78, 323-332. https://doi.org/10.1016/j.yqres.2012.06.002.

Corella, J.P., Moreno, A., Morellón, M., Rull, V., Giralt, S., Rico, M.T., Pérez-Sanz, A., ValeroGarcés, B.L., 2011. Climate and human impact on a meromictic lake during the last 6,000 years (Montcortès Lake, Central Pyrenees, Spain). J. Paleolimnol. 46, 351-367. https://doi.org/10.1007/s10933-010-9443-3.

Creus, J., Fernández, A., Manrique, E., 1996. Evolución de la temperatura y precipitación anuales desde el año 1400 en el sector central de la depresio'n del Ebro. Lucas Mallada 8, 9-27.

Creus, J., Saz, M.A., 1999. Estudio de la variabilidad climática del ultimo milenio a partir de series de temperatura y precipitación reconstruidas del NE español, in: Raso, J.M., Martin-Vide, J. (Eds.), La Climatología Española en los Albores del s. XXI. Public. Asoc. Esp. Climatol. Serie A, vol. 1. Asociación Española de Climatología, Barcelona, pp. $155-164$.

de Castro, M., Martín-Vide, J., Alonso, S., 2005. Clima de España: pasado, presente y escenarios de clima para el siglo XXI, in: Evaluación Preliminar de los Impactos en España por Efecto del Cambio Climático Proyecto ECCE - INFORME FINAL. Centro de Publicaciones, Secretaría General Técnica, Ministerio de Medio Ambiente, pp 1-64. 
De Luis, M., González-Hidalgo, J.C., Brunetti, M., Longares, L.A., 2011. Precipitation concentration changes in Spain 1946-2005. Nat. Hazards Earth Syst. Sci. 11, 1259-1265. https://doi.org/10.5194/nhess-11-1259-2011.

Domínguez-Castro, F., García-Herrera, R., Ribera, P., Barriendos, M., 2010. A shift in the spatial pattern of Iberian droughts during the 17th century. Clim. Past 6, 553-563. https://doi.org/10.5194/cp-6-553-2010.

Domínguez-Castro, F., Santisteban, J.I., Barriendos, M., Mediavilla, R., 2008. Reconstruction of drought episodes for central Spain from rogation ceremonies recorded at the Toledo Cathedral from 1506 to 1900: a methodological approach. Glob. Planet. Change 63, 230242. https://doi.org/10.1016/j.gloplacha.2008.06.002.

Dorado Liñán, I., Büntgen, U., González-Rouco, F., Zorita, E., Montávez, J.P., Gómez-Navarro, J.J., Brunet, M., Heinrich, I., Helle, G., Gutiérrez, E., 2012. Estimating 750 years of temperature variations and uncertainties in the Pyrenees by tree-ring reconstructions and climate simulations. Clim. Past 8, 919-933. https://doi.org/10.5194/cp-8-919-2012.

Dorado Liñán, I., Zorita, E., González-Rouco, J.F., Heinrich, I., Campello, F., Muntán, E., Andreu-Hayles, L., Gutiérrez, E., 2015. Eight-hundred years of summer temperature variations in the southeast of the Iberian Peninsula reconstructed from tree rings. Clim. Dyn. 44, 75-93. https://doi.org/10.1007/s00382-014-2348-5.

Eddy, J.A., 1976. The Maunder minimum. Science 192, 1189-1202. https://doi.org/10.1126/science.192.4245.1189.

Enfield, D.B., Mestas-Nuñez, A.M., Trimble, P.J., 2001. The Atlantic Multidecadal Oscillation and its relation to rainfall and river flows in the continental U.S. Geophys. Res. Lett. 28, 2077-2080. https://doi.org/10.1029/2000g1012745. 
Fernández, J., Casanueva, A., Montávez, J.P., Gaertner, M.A., Casado Calle, M.J., Manzanas, R., Gutiérrez Llorente, J.M., 2017. Regional climate projections over Spain: atmosphere. Future climate projections. CLIVAR Exch. 73, 45-52.

Gajewski, K., Hamilton, P.B., McNeely, R., 1997. A high resolution proxy-climate record from an arctic lake with annually-laminated sediments on Devon Island, Nunavut, Canada. J. Paleolimnol. 17, 215-225. https://doi.org/10.1023/A:1007984617675.

García-Ruiz, J.M., White, S.M., Martí, C., Valero, B., Errea, M.P., Gómez Villar, A., 1996. La catástrofe del barranco de Arás (Biescas, Pirineo aragonés) y su contexto espaciotemporal. Instituto Pirenaico de Ecología, CSIC, Zaragoza.

Génova, M., 2012. Extreme pointer years in tree-ring records of Central Spain as evidence of climatic events and the eruption of the Huaynaputina Volcano (Peru, 1600 AD). Clim. Past 8, 751-764. https://doi.org/10.5194/cp-8-751-2012.

Gonzalez-Hidalgo, J.C., Lopez-Bustins, J.A., Štepánek, P., Martin-Vide, J., de Luis, M., 2009. Monthly precipitation trends on the Mediterranean fringe of the Iberian Peninsula during the second-half of the twentieth century (1951-2000). Int. J. Climatol. 29, 1415-1429. https://doi.org/10.1002/joc. 1780.

Hammer, Ø., Harper, D.A.T., Ryan, P.D., 2001. PAST: paleontological statistics software package for education and data analysis. Palaeontol. Electron. 4, 9.

Hardy, D.R., Bradley, R.S., Zolitschka, B., 1996. The climatic signal in varved sediments from Lake C2, northern Ellesmere Island, Canada. J. Paleolimnol. 16, 227-238. https://doi.org/10.1007/BF00176938. 
Hughen, K.A., Overpeck, J.T., Anderson, R.F., 2000. Recent warming in a 500-year palaeotemperature record from varved sediments, Upper Soper Lake, Baffin Island, Canada. Holocene 10, 9-19. https://doi.org/10.1191/095968300676746202.

IPCC, 2021. Summary for policymakers, in: Masson-Delmotte, V., Zhai, P., Pirani, A., Connors, S.L., Péan, C., Berger, S., Caud, N., Chen, Y., Goldfarb, L., Gomis, M.I., Huang, M., Leitzell, K., Lonnoy, E., Matthews, J.B.R., Maycock, T.K., Waterfield, T., Yelekçi, O., Yu, R., Zhou, B. (Eds.), Climate Change 2021: The Physical Science Basis. Contribution of Working Group I to the Sixth Assessment Report of the Intergovernmental Panel on Climate Change. Cambridge University Press, Cambridge, pp. 1-41.

Jones, P.D., Hulme, M., 1996. Calculating regional climatic time series for temperature and precipitation: methods and illustrations. Int. J. Climatol. 16, 361-377. https://doi.org/10.1002/(sici)1097-0088(199604)16:4<361::aid-joc53>3.0.co;2-f.

Kabacoff, R.I., 2011. R in Action. Data Analysis and Graphics with R. Manning Publications Co., USA.

Knight, J.R., Folland, C.K., Scaife, A.A., 2006. Climate impacts of the Atlantic Multidecadal Oscillation. Geophys. Res. Lett. 33, L17706. https://doi.org/10.1029/2006g1026242.

Koutsodendris, A., Brauer, A., Reed, J.M., Plessen, B., Friedrich, O., Hennrich, B., Zacharias, I., Pross, J., 2017. Climate variability in SE Europe since 1450 AD based on a varved sediment record from Etoliko Lagoon (Western Greece). Quat. Sci. Rev. 159, 63-76. https://doi.org/10.1016/j.quascirev.2017.01.010.

Lionello, P., Abrantes, F., Congedi, L., Dulac, F., Gacic, M., Gomis, D., Goodess, C., Hoff, H., Kutiel, H., Luterbacher, J., Planton, S., Reale, M., Schröder, K., Vittoria Struglia, M., Toreti, A., Tsimplis, M., Ulbrich, U., Xoplaki, E., 2012. Introduction: Mediterranean 
climate-background information, in: Lionello, P. (Ed.), The Climate of the Mediterranean Region. Elsevier, Oxford, pp. xxxv-xc.

Lopez-Bustins, J.A., Lemus-Canovas, M., 2020. The influence of the Western Mediterranean Oscillation upon the spatio-temporal variability of precipitation over Catalonia (northeastern of the Iberian Peninsula). Atmos. Res. 236, 104819. https://doi.org/10.1016/j.atmosres.2019.104819.

López-Moreno, J.I., Beniston, M., 2009. Daily precipitation intensity projected for the 21 st century: seasonal changes over the Pyrenees. Theor. Appl. Climatol. 95, 375-384.

Lopez Laseras, Ma. Pilar. «Sedimentary phosphorus dynamics in epicontinental systems: A literature review». Oecol. aquat.10, 113-25.

Lotter, A., Birks, H.J.B. 1997. The separation of the influence of nutrients and climate on the varve time-series of Baldeggersee, Switzerland. Aquat. Sci. 59, 362-375

Luterbacher, J., García-Herrera, R., Akcer-On, S., Allan, R., Alvarez-Castro, M.-C., Benito, G., Booth, J., Büntgen, U., Cagatay, N., Colombaroli, D., Davis, B., Esper, J., Felis, T., Fleitmann, D., Frank, D., Gallego, D., Garcia-Bustamante, E., Glaser, R., GonzalezRouco, F.J., Goosse, H., Kiefer, T., Macklin, M.G., Manning, S.W., Montagna, P., Newman, L., Power, M.J., Rath, V., Ribera, P., Riemann, D., Roberts, N., Sicre, M.-A., Silenzi, S., Tinner, W., Tzedakis, P.C., Valero-Garcés, B., van der Schrier, G., Vannière, B., Vogt, S., Wanner, H., Werner, J.P., Willett, G., Williams, M.H., Xoplaki, E., Zerefos, C.S., Zorita, E., 2012. A review of 2000 years of paleoclimatic evidence in the Mediterranean, in: Lionello, P. (Ed.), The Climate of the Mediterranean Region. Elsevier, Oxford, pp. 87-185. 
Macias-Fauria, M., Grinsted, A., Helama, S., Holopainen, J., 2012. Persistence matters: estimation of the statistical significance of paleoclimatic reconstruction statistics from autocorrelated time series. Dendrochronologia 30, 179-187. https://doi.org/10.1016/j.dendro.2011.08.003.

Maier, D.B., Rydberg, J., Bigler, C., Renberg, I., 2013. Compaction of recent varved lake sediments. J. Geol. Soc. Swed. 135, 231-236. https://doi.org/10.1080/11035897.2013.788551.

Mariotti, A., Dell'Aquila, A., 2012. Decadal climate variability in the Mediterranean region: roles of large-scale forcings and regional processes. Clim. Dyn. 38, 1129-1145. https://doi.org/10.1007/s00382-011-1056-7.

Martín-Puertas, C., Valero-Garcés, B.L., Pilar Mata, M., González-Sampériz, P., Bao, R., Moreno, A., Stefanova, V., 2008. Arid and humid phases in southern Spain during the last 4000 years: the Zoñar Lake record, Córdoba. Holocene 18, 907-921. https://doi.org/10.1177/0959683608093533.

Martin-Vide, J., Lopez-Bustins, J.-A., 2006. The Western Mediterranean Oscillation and rainfall in the Iberian Peninsula. Int. J. Climatol. 26, 1455-1475. https://doi.org/10.1002/joc.1388.

Mercadé, A., Vigo, J., Rull, V., Vegas-Villarrúbia, T., Garcés, S., Lara, A., Cañellas-Boltà, N., 2013. Vegetation and landscape around Lake Montcortès (Catalan pre-Pyrenees) as a tool for palaeoecological studies of lake sediments. Collect. Bot. 32, 87-101.

Meteocat, 2015. Climatologia. El Pallars Jussà. 1961-1990. https://static$\underline{\text { m.meteo.cat/wordpressweb/wp-content/uploads/2014/11/13083422/PallarsJussa.pdf }}$ 
Mestre, O., Domonkos, P., Picard, F., Auer, I., Robin, S., Lebarbier, E., Böhm, R., Aguilar, E., Guijarro, J., Vertachnik, G., Klancar, M., Dubuisson, B., Stepanek, P., 2013. HOMER: a homogenization software - methods and applications. IDÖJÁRÁS 117, 47-67.

Morellón, M., Pérez-Sanz, A., Corella, J.P., Büntgen, U., Catalán, J., González-Sampériz, P., González-Trueba, J.J., López-Sáez, J.A., Moreno, A., Pla-Rabes, S., Saz-Sánchez, M.Á., Scussolini, P., Serrano, E., Steinhilber, F., Stefanova, V., Vegas-Vilarrúbia, T., ValeroGarcés, B., 2012. A multi-proxy perspective on millennium-long climate variability in the Southern Pyrenees. Clim. Past 8, 683-700. https://doi.org/10.5194/cp-8-683-2012.

Morellón, M., Valero-Garcés, B., González-Sampériz, P., Vegas-Vilarrúbia, T., Rubio, E., Rieradevall, M., Delgado-Huertas, A., Mata, P., Romero, Ó., Engstrom, D.R., LópezVicente, M., Navas, A., Soto, J., 2011. Climate changes and human activities recorded in the sediments of Lake Estanya (NE Spain) during the Medieval Warm Period and Little Ice Age. J. Paleolimnol. 46, 423-452. https://doi.org/10.1007/s10933-009-9346-3.

Moreno, A., Pérez-Mejías, C., Bartolomé, M., Sancho, C., Cacho, I., Stoll, H., Delgado-Huertas, A., Hellstrom, J., Edwards, R.L., Cheng, H., 2017. New speleothem data from Molinos and Ejulve caves reveal Holocene hydrological variability in northeast Iberia. Quat. Res. 88, 223-233. https://doi.org/10.1017/qua.2017.39.

Moreno, A., Pérez, A., Frigola, J., Nieto-Moreno, V., Rodrigo-Gámiz, M., Martrat, B., GonzálezSampériz, P., Morellón, M., Martín-Puertas, C., Corella, J.P., Belmonte, Á., Sancho, C., Cacho, I., Herrera, G., Canals, M., Grimalt, J.O., Jiménez-Espejo, F., Martínez-Ruiz, F., Vegas-Vilarrúbia, T., Valero-Garcés, B.L., 2012. The Medieval Climate Anomaly in the Iberian Peninsula reconstructed from marine and lake records. Quat. Sci. Rev. 43, 16-32. https://doi.org/10.1016/j.quascirev.2012.04.007. 
Muñoz-Díaz, D., Rodrigo, F.S., 2005. Influence of the El Niño-Southern Oscillation on the probability of dry and wet seasons in Spain. Clim. Res. 30, 1-12. https://doi.org/10.3354/cr030001.

Oliva, M., Ruiz-Fernández, J., Barriendos, M., Benito, G., Cuadrat, J.M., Domínguez-Castro, F., García-Ruiz, J.M., Giralt, S., Gómez-Ortiz, A., Hernández, A., López-Costas, O., LópezMoreno, J.I., López-Sáez, J.A., Martínez-Cortizas, A., Moreno, A., Prohom, M., Saz, M.A., Serrano, E., Tejedor, E., Trigo, R., Valero-Garcés, B., Vicente-Serrano, S.M., 2018. The Little Ice Age in Iberian mountains. Earth Sci. Rev. 177, 175-208. https://doi.org/10.1016/j.earscirev.2017.11.010.

OPCC-CTP, 2018. El Cambio Climático en los Pirineos: Impactos, Vulnerabilidades y Adaptación. Bases de Conocimiento para la Futura Estrategia de Adaptación al Cambio Climático en los Pirineos. OPCC-CTP, Jaca.

Osborn, T.J., Briffa, K.R., Jones, P.D., 1997. Adjusting variance for sample-size in tree-ring chronologies and other regional mean time series. Dendrochronologia 15, 89-99.

Pérez-Zanón, N., Sigró, J., Ashcroft, L., 2016. Temperature and precipitation regional climate series over the central Pyrenees during 1910-2013. Int. J. Climatol. 37, 1922-1937. https://doi.org/10.1002/joc.4823.

Pisano, A., Marullo, S., Artale, V., Falcini, F., Yang, C., Leonelli, F.E., Santoleri, R., Buongiorno Nardelli, B., 2020. New evidence of Mediterranean climate change and variability from sea surface temperature observations. Remote Sens. 12, 132. https://doi.org/10.3390/rs12010132. 
Pla, S., Catalan, J., 2005. Chrysophyte cysts from lake sediments reveal the submillennial winter/spring climate variability in the northwestern Mediterranean region throughout the Holocene. Clim. Dyn. 24, 263-278. https://doi.org/10.1007/s00382-004-0482-1.

Prohom, M., Barriendos, M., Sanchez-Lorenzo, A., 2015. Reconstruction and homogenization of the longest instrumental precipitation series in the Iberian Peninsula (Barcelona, 17862014). Int. J. Climatol. 36, 3072-3087. https://doi.org/10.1002/joc.4537.

Quinn, J.P., Keough, M.J., 2007. Experimental Design and Data Analysis for Biologists. Cambridge University Press, Cambridge.

Rick, T., Ontiveros, M.Á.C., Jerardino, A., Mariotti, A., Méndez, C., Williams, A.N., 2020. Human-environmental interactions in Mediterranean climate regions from the Pleistocene to the Anthropocene. Anthropocene 31, 100253. https://doi.org/10.1016/j.ancene.2020.100253.

Riera, S., Wansard, G., Julià, R., 2004. 2000-year environmental history of a karstic lake in the Mediterranean Pre-Pyrenees: the Estanya lakes (Spain). CATENA 55, 293-324. https://doi.org/10.1016/s0341-8162(03)00107-3.

Roberts, N., Moreno, A., Valero-Garcés, B.L., Corella, J.P., Jones, M., Allcock, S., Woodbridge, J., Morellón, M., Luterbacher, J., Xoplaki, E., Türkeş, M., 2012. Palaeolimnological evidence for an east-west climate see-saw in the Mediterranean since AD 900. Glob. Planet. Change 84-85, 23-34. https://doi.org/10.1016/j.gloplacha.2011.11.002.

Rodrigo, F.S., Barriendos, M., 2008. Reconstruction of seasonal and annual rainfall variability in the Iberian peninsula (16th-20th centuries) from documentary data. Glob. Planet. Change 63, 243-257. https://doi.org/10.1016/j.gloplacha.2007.09.004. 
Rodrigo, F.S., Esteban-Parra, M.J., Pozo-Vázquez, D., Castro-Díez, Y., 1999. A 500-year precipitation record in Southern Spain. Int. J. Climatol. 19, 1233-1253. https://doi.org/10.1002/(sici)1097-0088(199909)19:11<1233::aid-joc413>3.0.co;2-1.

Rodriguez-Puebla, C., Encinas, A.H., Nieto, S., Garmendia, J., 1998. Spatial and temporal patterns of annual precipitation variability over the Iberian Peninsula. Int. J. Climatol. 18, 299-316. https://doi.org/10.1002/(sici)1097-0088(19980315)18:3<299::aidjoc247>3.0.co;2-1.

Romero-Viana, L., Julià, R., Camacho, A., Vicente, E., Miracle, M.R., 2008. Climate signal in varve thickness: Lake La Cruz (Spain), a case study. J. Paleolimnol. 40, 703-714. https://doi.org/10.1007/s10933-008-9194-6.

Romero-Viana, L., Julià, R., Schimmel, M., Camacho, A., Vicente, E., Miracle, M.R., 2011. Reconstruction of annual winter rainfall since A.D.1579 in central-eastern Spain based on calcite laminated sediment from Lake La Cruz. Clim. Change 107, 343-361. https://doi.org/10.1007/s10584-010-9966-7.

Rosell, J., 1994. Geological Map of Spain and Report. Scale 1: 50,000, Tremp Sheet (252). Instituto Tecnológico Geográfico de España (IGME), Madrid.

Rull, V., 2015. Long-term vegetation stability and the concept of potential natural vegetation in the Neotropics. J. Veg. Sci. 26, 603-607. https://doi.org/10.1111/jvs.12278.

Rull, V., Vegas-Vilarrúbia, T., 2014. Preliminary report on a mid-19th century Cannabis pollen peak in NE Spain: historical context and potential chronological significance. Holocene 24, 1378-1383. https://doi.org/10.1177/0959683614540964.

Rull, V., Vegas-Vilarrúbia, T., Corella, J.P., Trapote, M.C., Montoya, E., Valero-Garcés, B., 2021a. A unique Pyrenean varved record provides a detailed reconstruction of 
Mediterranean vegetation and land-use dynamics over the last three millennia. Quat. Sci. Rev. 268, 107128. https://doi.org/10.1016/j.quascirev.2021.107128.

Rull, V., Vegas-Vilarrúbia, T., Corella, J.P., Valero-Garcés, B., 2021b. Bronze Age to Medieval vegetation dynamics and landscape anthropization in the southern-central Pyrenees. Palaeogeogr. Palaeoclimatol. Palaeoecol. 571, 110392. https://doi.org/10.1016/j.palaeo.2021.110392.

Schlesinger, M.E., Ramankutty, N., 1994. An oscillation in the global climate system of period 65-70 years. Nature 367, 723-726. https://doi.org/10.1038/367723a0.

Serrano-Muela, M.P., Nadal-Romero, E., Lana-Renault, N., González-Hidalgo, J.C., LópezMoreno, J.I., Beguería, S., Sanjuan, Y., García-Ruiz, J.M., 2013. An exceptional rainfall event in the Central Western Pyrenees: spatial patterns in discharge and impact. Land Degrad. Dev. 26, 249-262. https://doi.org/10.1002/ldr.2221.

Stoll, H.M., Moreno, A., Mendez-Vicente, A., Gonzalez-Lemos, S., Jimenez-Sanchez, M., Dominguez-Cuesta, M.J., Edwards, R.L., Cheng, H., Wang, X., 2013. Paleoclimate and growth rates of speleothems in the northwestern Iberian Peninsula over the last two glacial cycles. Quat. Res. 80, 284-290. https://doi.org/10.1016/j.yqres.2013.05.002.

Sutton, R.T., Hodson, D.L.R., 2005. Atlantic ocean forcing of North American and European Summer Climate. Science 309, 115-118. https://doi.org/10.1126/science.1109496.

Torrence, C., Compo, G.P., 1998. A practical guide to wavelet analysis. Bull. Am. Meteorol. Soc. 79, 61-78. https://doi.org/10.1175/1520-0477(1998)079<0061:apgtwa $>2.0 . c 0 ; 2$.

Trapote, M.C., Rull, V., Giralt, S., Corella, J.P., Montoya, E., Vegas-Vilarrúbia, T., 2018a. Highresolution (sub-decadal) pollen analysis of varved sediments from Lake Montcortès (southern Pyrenean flank): a fine-tuned record of landscape dynamics and human impact 
during the last 500 years. Rev. Palaeobot. Palynol. 259, 207-222.

https://doi.org/10.1016/j.revpalbo.2018.10.002.

Trapote, M.C., Vegas-Vilarrúbia, T., López, P., Puche, E., Gomà, J., Buchaca, T., Cañellas-

Boltà, N., Safont, E., Corella, J.P., Rull, V., 2018b. Modern sedimentary analogues and integrated monitoring to understand varve formation in the Mediterranean Lake Montcortès (Central Pyrenees, Spain). Palaeogeogr. Palaeoclimatol. Palaeoecol. 496, 292-304. https://doi.org/10.1016/j.palaeo.2018.01.046.

Trigo, R.M., Pozo-Vázquez, D., Osborn, T.J., Castro-Díez, Y., Gámiz-Fortis, S., Esteban-Parra, M.J., 2004. North Atlantic oscillation influence on precipitation, river flow and water resources in the Iberian Peninsula. Int. J. Climatol. 24, 925-944. https://doi.org/10.1002/joc.1048.

Vegas-Vilarrúbia, T., Corella, J.P., Pérez-Zanón, N., Buchaca, T., Trapote, M.C., López, P., Sigró, J., Rull, V., 2018. Historical shifts in oxygenation regime as recorded in the laminated sediments of lake Montcortès (Central Pyrenees) support hypoxia as a continental-scale phenomenon. Sci. Total Environ. 612, 1577-1592. https://doi.org/10.1016/j.scitotenv.2017.08.148.

Vegas-Vilarrúbia, T., Rull, V., Trapote, M.d.C., Cao, M., Rosell-Melé, A., Buchaca, T., Gomà, J., López, P., Sigró, J., Safont, E., Cañellas, N., Garcés-Pastor, S., Giralt, S., Corella, J.P., Pérez-Zanón, N., 2020. Modern analogue approach applied to high-resolution varved sediments - a synthesis for lake Montcortès (Central Pyrenees). Quaternary 3, 1. https://doi.org/10.3390/quat3010001.

Venema, V.K.C., Mestre, O., Aguilar, E., Auer, I., Guijarro, J.A., Domonkos, P., Vertacnik, G., Szentimrey, T., Stepanek, P., Zahradnicek, P., Viarre, J., Müller-Westermeier, G., 
Lakatos, M., Williams, C.N., Menne, M.J., Lindau, R., Rasol, D., Rustemeier, E., Kolokythas, K., Marinova, T., Andresen, L., Acquaotta, F., Fratianni, S., Cheval, S., Klancar, M., Brunetti, M., Gruber, C., Prohom Duran, M., Likso, T., Esteban, P., Brandsma, T., 2012. Benchmarking homogenization algorithms for monthly data. Clim. Past 8, 89-115. https://doi.org/10.5194/cp-8-89-2012.

Xoplaki, E., González-Rouco, J.F., Luterbacher, J., Wanner, H., 2004. Wet season Mediterranean precipitation variability: influence of large-scale dynamics and trends. Clim. Dyn. 23, 63-78. https://doi.org/10.1007/s00382-004-0422-0.

Zhang, R., Delworth, T.L., 2006. Impact of Atlantic multidecadal oscillations on India/Sahel rainfall and Atlantic hurricanes. Geophys. Res. Lett. 33, L17712. https://doi.org/10.1029/2006g1026267.

Zhang, Z., Moore, J., 2011. Intrinsic feature extraction in the COI of wavelet power spectra of climatic signals, in: 2011 4th International Congress on Image and Signal Processing. IEEE, Shanghai, China, pp. 2354-2356. 